POOR LITTLE CHILDREN: THE SOCIOECONOMIC GAP IN PARENTAL RESPONSES TO SCHOOL DISADVANTAGE

$08 / 11 / 2017$

$N^{\circ} 2017 / 23$

\title{
POOR LITTLE CHILDREN: THE SOCIOECONOMIC GAP IN PARENTAL RESPONSES TO SCHOOL DISADVANTAGE
}

Berniell, I.

Estrada, R. 


\section{POOR LITTLE CHILDREN: THE SOCIOECONOMIC GAP IN PARENTAL RESPONSES TO SCHOOL DISADVANTAGE}

Berniell, I.

Estrada, R.

CAF - Working paper $N^{\circ} 2017 / 23$

$08 / 11 / 2017$

\section{ABSTRACT}

In this paper, we study how parents react to a widely-used school policy that puts some children at a learning disadvantage. Specifically, we first document that, in line with findings in other countries, younger children in Spain perform significantly worse at school than their older peers and - key to causal interpretation - that for children born in winter this effect is not due to birth seasonality. Furthermore, the age of school entry effect is significantly greater among children from disadvantaged families. To understand why, we analyze detailed data on parental investment and find that college-educated parents increase their time investment and choose schools with better inputs when their children are the youngest at school entry, while non-collegeeducated parents do not.

Small sections of text, that are less than two paragraphs, may be quoted without explicit permission as long as this document is stated. Findings, interpretations and conclusions expressed in this publication are the sole responsibility of its author(s), and it cannot be, in any way, attributed to CAF, its Executive Directors or the countries they represent. CAF does not guarantee the accuracy of the data included in this publication and is not, in any way, responsible for any consequences resulting from its use. 


\section{POOR LITTLE CHILDREN: LA BRECHA SOCIOECONÓMICA EN LA RESPUESTA DE LOS PADRES DE FAMILIA ANTE LA DESVENTAJA ESCOLAR}

Berniell, I.

Estrada, R.

CAF - Documento de trabajo $N^{\circ} 2017 / 23$

$08 / 11 / 2017$

\section{RESUMEN}

En este estudio, analizamos la respuesta de los padres de familia a una política escolar que pone a algunos niños en situación de desventaja de aprendizaje con respecto a sus pares. En específico, utilizamos datos de España para investigar los efectos de la política que define la edad (exacta) en la cual los niños deben iniciar la educación primaria. En primera instancia, documentamos que los niños que inician la escuela a una edad más temprana tienen un peor desempeño escolar que sus pares de mayor edad - lo cual es consistente con la evidencia existente a nivel internacional. Asimismo, mostramos que entre aquellos individuos nacidos durante el invierno las diferencias observadas en el desempeño escolar no son el resultado de patrones de estacionalidad en los nacimientos, lo cual es necesario para una interpretación causal de este efecto. Más aun, encontramos que el efecto de la edad al inicio de la escuela es considerablemente mayor entre los niños de estatus socioeconómico bajo. Para entender esta brecha socioeconómica, analizamos datos sobre las inversiones educativas que realizan las familias. Así, encontramos que cuando sus hijos son relativamente más jóvenes al iniciar la escuela, los padres de familia con educación universitaria aumentan el tiempo que pasan ayudándoles en actividades académicas y eligen para ellos escuelas con más insumos educativos. Por el contrario, los padres de familia sin educación universitaria no cambian estos patrones de inversión educativa según la edad de sus hijos al inicio de la educación primaria.

Small sections of text, that are less than two paragraphs, may be quoted without explicit permission as long as this document is stated. Findings, interpretations and conclusions expressed in this publication are the sole responsibility of its author(s), and it cannot be, in any way, attributed to CAF, its Executive Directors or the countries they represent. CAF does not guarantee the accuracy of the data included in this publication and is not, in any way, responsible for any consequences resulting from its use. 


\title{
Poor Little Children: The Socioeconomic Gap in Parental Responses to School Disadvantage*
}

\author{
Inés Berniell ${ }^{\dagger} \quad$ Ricardo Estrada ${ }^{\ddagger}$
}

November 8, 2017

\begin{abstract}
In this paper, we study how parents react to a widely-used school policy that puts some children at a learning disadvantage. Specifically, we first document that, in line with findings in other countries, younger children in Spain perform significantly worse at school than their older peers and - key to causal interpretation - that for children born in winter this effect is not due to birth seasonality. Furthermore, the age of school entry effect is significantly greater among children from disadvantaged families. To understand why, we analyze detailed data on parental investment and find that college-educated parents increase their time investment and choose schools with better inputs when their children are the youngest at school entry, while non-college-educated parents do not.
\end{abstract}

Keywords: parental investment, age at school entry, education inequality, compensating behaviour.

JEL Classification: I20, D10

*Acknowledgments: We thank Manuel Bagues and Andrea Ichino for detailed comments. We also thank Lian Allub, Fabrizio Bernardi, Lucila Berniell, Gabriel Fachini, Gabriela Galassi and the audiences at the Universidad de Buenos Aires, CAF, EUI Microeconometrics Working Group, the EUI Max Weber Conference, the IEA World Congress at CIDE, the IZA Economics of Education Workshop and NAMES at Washington University in St. Louis for valuable insights. We are grateful to Marta Encinas and François Keslair for their expertise and help with handling OECD data and to the Max Weber Programme at the EUI for funding during the start of this project. All errors are our own.

${ }^{\dagger}$ CEDLAS (Center for Distributional, Labor and Social Studies), Universidad Nacional de La Plata, Calle 6 Nro. 777, La Plata, Argentina, email: ines.berniell@econo.unlp.edu.ar.

$\ddagger$ CAF-Development Bank of Latin America, Avenida Madero 900, Piso 15, Torre Catalinas Plaza, Ciudad de Buenos Aires, Argentina, email: restrada@caf.com. 


\section{Introduction}

Life (policy) can put some children at a disadvantage. If this is the case, parents can react to disadvantage by changing their investment in their children and, potentially, mitigate it. However, parental reactions might depend on parental resources, with important implications for inequality and social mobility and for policy impacts. Our understanding of such responses is limited, however, because a proper empirical analysis requires both exogenous variation in exposure to disadvantage and the availability of detailed data on parental investment.

In this paper, we study how parents from different socioeconomic statuses (SES) react to a widely-used school policy that puts some children at a learning disadvantage: the age at school entry. Most countries dictate that children born during a given one-year period should start school at the same time. This (up to one-year) difference in the age of students in the same classroom can be reflected in performance. For instance, younger children might be less ready to acquire knowledge and, overall, to deal with the experience of formal schooling. If initial outcomes shape future outcomes, the age at school entry can have long-term consequences for schooling and labour market trajectories (see Subsection 2.1).

A large body of literature shows that starting school at an earlier age is indeed related to worse student performance and labour market outcomes, and criminal behaviour. ${ }^{1}$ Furthermore, this negative effect might be greater among people from a disadvantaged background, at least in some contexts (Grätz and Bernardi, 2017 on England; and Fredriksson and Öckert, 2014 on Sweden). To understand why, we use detailed information on parental investment in Spain to study how parents from different SES react to differences in age at school entry.

In the empirical analysis, we first document that younger children tend to perform worse in school than older children in Spain. Using data from four waves of the PISA survey, we find that students who started school at a younger age are more likely to have repeated a grade and to have lower test scores in mathematics and reading at age 15 than their older peers. For example, students born in December (the youngest in their cohort) are 10 percentage points more likely to have repeated a grade at age 15 than those born in January (the oldest). ${ }^{2}$ We go further and explore how this pattern translates into long-term outcomes, using information from the Spanish population census. We find that

\footnotetext{
${ }^{1}$ For student outcomes, see for example: Bedard and Dhuey, 2006 and Elder and Lubotsky, 2009 on the United States; Mühlenweg and Puhani, 2010 on Germany; Grenet, 2011 on France. For the effect on the probability of ADHD diagnoses: Schwandt and Wuppermann, 2016; Elder, 2010. For criminal behaviour: Cook and Kang (2016) and Landersø, Nielsen, and Simonsen, 2016 on the United States and Denmark, respectively. For labour market outcomes: Fredriksson and Öckert, 2014 on Sweden; Bedard and Dhuey, 2012 and Dhuey and Lipscomb, 2008 on the United States; and Black et al., 2011 on Norway. The latter document that this age effect on earnings dilutes when people reach 30 in Norway.

${ }^{2}$ This pattern echoes the findings of Calsamiglia and Loviglio (2016) on Catalonia.
} 
adults who were younger at school entry have less schooling and less educated partners.

A causal interpretation of the documented age effect requires that 1) parents do not manipulate their child's effective age of school entry (by postponing enrollment for one year); and 2) there is no connection between the characteristics of newborns and their month of birth. Some parents might be willing to enroll their children in school later than regular entry if they are sufficiently concerned about the negative effects associated with the age at school entry. ${ }^{3}$ Spain enforces a strict birthday cut-off for school entry, so, even if they wish to, parents cannot opt for strategy 1). Alternatively, there could be a connection between the characteristics of newborns and the month of birth if parental characteristics or relevant environmental (institutional) conditions that shape fetal (newborn) health vary during the year. ${ }^{4}$

We analyze the birth certificates from the universe of newborns in Spain from 2007 to 2014 to study potential seasonality in births. ${ }^{5}$ Using census-type data allows us to detect birth patterns that could go unnoticed in survey data because of a small sample size. We find that there is indeed some seasonality in births. However, and this is key for a causal interpretation, we do not find significant differences in the characteristics of babies born in December and January (just before and after the birthday cut-off for entry to school, which is January 1st).

We, therefore, focus our analysis on people born in January (the oldest at school entry) and December (the youngest). Using data from PISA, we show that the effect of the age of school entry is significantly larger among children from disadvantaged families. For instance, young students from low-SES families are 12.7 percentage points more likely to have repeated a grade at age 15 than older students from the same socioeconomic background. This gap is only 4 percentage points among students from high-SES families.

To analyse whether this difference is related to parental responses according to family background, we assemble two different datasets with detailed information about parental investment: the two waves of the Spanish Time Use Survey (2003 and 2009, STUS) and the General Diagnostic Assessment (a national evaluation of 4th grade students undertaken in 2009, GDA), which has information about parental involvement and school characteristics. Our focus on parental time investment in child development is grounded in the literature which shows that parental time input is important for the cognitive development of their children, particularly when they are young (Del Boca, Flinn, and Wiswall, 2014). We find that college-educated parents increase the amount of time they spend helping their children with school activities and that they choose schools with better inputs when their children are the youngest at school entry, while parents without

\footnotetext{
${ }^{3}$ Dhuey, Figlio, Karbownik, and Roth, 2017 document that postponing school enrollment is a common practice in the United States.

${ }^{4}$ Along these lines, Buckles and Hungerman (2013) documents seasonality in maternal characteristics in the United States.

${ }^{5} 2007$ is the first year in which parental characteristics are available in the birth certificate data.
} 
a college education do not. Supporting the idea that the differences in parental time investment are related to what happens at school, from the STUS we only observe that parents invest more time in helping their younger children with academic tasks when they are of school age, and not when they are of pre-school age.

Finally, we deepen our analysis by looking at gender differences. Here, we observe different gender patterns among children from high-SES families. On the one hand, younger boys from high-SES families do not seem to be able to overcome the school entry age disadvantage by the age of 15 , and probably because they face a larger disadvantage they receive more parental help with homework and other academic activities. On the other hand, younger girls from high-SES families do not have different achievement levels at age 15 to their older peers, and probably because they face a smaller disadvantage, they do not receive more parental help than older girls from the same SES families. We find no such gender specific effect among children from low-SES families.

Our results highlight the importance of considering behavioral responses to policy for the impact evaluation literature based on reduced-form estimates. The reduced-form effects of a policy include both a direct (policy) effect and an indirect effect consisting of endogenous responses to the policy - in our case, parental responses to the school-entry age (Todd and Wolpin, 2003). To disentangle policy effects and production function parameters, we need to understand behavioural responses to policies. Surprisingly, there are few studies exploiting quasi-experiments that do this.

Specifically, we contribute to the ample literature on the effects of age at school entry. Here, we provide novel evidence on a mechanism behind the heterogeneous effect of age at school entry according to SES: differences in parental investment in terms of time and school choice. In a contemporaneous work, Dhuey et al. (2017) use data from the state of Florida in the United States to show that high-SES parents are more likely than low-SES parents to postpone the enrollment of their children in school by one year (a possible practice in that context). Their results support our findings: high-SES parents are more likely to help their children to deal with disadvantage.

We also contribute to the emerging literature on parental reactions to school policies (see Pop-Eleches and Urquiola; and Das et al., 2013). ${ }^{6}$ We contribute to this literature by highlighting how these reactions might vary according to parental SES and student's gender, and by providing more detailed evidence on parental responses. In the closest study to ours, Fredriksson et al. (2015) show that larger class sizes in Sweden increase the likelihood that high-income parents help their children with their homework and low-income parents move their children to a different school. Relative to this paper, we make two contributions. First, we use richer measures of parental investment, which allows to obtain a more comprehensive picture of changes in parental time investment

\footnotetext{
${ }^{6}$ On the thoretical side, Albornoz et al. (2016) develop a model in which parents compensate for lower educational quality, i.e. public and private investments in a child's human capital are substitutes.
} 
and school inputs, and to analyze how responses in parental time investments evolve over their children's life cycle. Second, we look at whether parental responses depend on the interaction between parental SES and their children's gender. ${ }^{7}$

The rest of the paper is organized as follows. Section 2 elaborates on the relationship between age at school entry and student outcomes, and describes the institutional framework. Section 3 presents the data and Section 4 the identification strategy. Section 5 describes the results for age at school entry, and Section 6 analyses of parental responses and the differences in these responses according to the child's age and gender. Section 7 concludes.

\section{Age at School Entry}

\subsection{How Can Age at School Entry Affect Schooling Outcomes?}

The specialized literature has devoted much attention to the issue of how age at school entry can affect student (and adult) outcomes (see, for example, Crawford et al., 2007). These effects are typically categorized as 1) age at starting school, 2) age at testing, 3) relative age and 4) length of schooling.

1. As age is a determinant of maturity, younger children at school entry might be less ready to acquire knowledge and, overall, to deal with the experience of formal schooling (Dhuey, 2016). Moreover, because of their age, older students are more likely to have accumulated a higher stock of skills at school entry than their younger classmates, which could also help them to learn more in school.

2. If all the children in a school cohort are examined on the same day, then students are examined at different ages and some students are always younger than their peers.

3. Younger students might perform worse because they are younger than their peers if, for example, differences in absolute performance due to maturity affect the accumulation of skills like self-confidence.

4. The time students spend in the education system might depend on regulations about the timing when students can enter (leave) formal schooling.

The relevance of these effects in shaping student and adult outcomes might depend on the structure of the education system. For example, the level of maturity at school entry is likely to be more important in countries that teach the same (ambitious) curriculum to

\footnotetext{
${ }^{7} \mathrm{~A}$ related literature analyses how parental investment responds to health endowment at birth. The empirical evidence suggests that parental investment reinforces initial differences in health endowments, although there are some indications that high-income parents might be more prone to compensating behavior (see the literature review in Almond and Mazumder, 2013).
} 
all students independently of their achievement levels - as is the case in Spain. The same story goes for contexts where grade retention is commonly used - such as Spain. Younger - and less mature - students might be more likely to repeat a grade, which might be detrimental to them if it is associated with negative stereotypes or a loss of self-esteem. The use of (rigid) tracking based on early achievement levels might set younger students on different educational trajectories - ones with access to fewer school inputs - than their older peers. Similarly, age at testing can affect educational trajectories if grades or other measures used to assess student performance are not adjusted for age. Grenet (2011) gives a more complete discussion of how the structure of education systems can amplify initial differences in performance due to age at school entry.

Summing up, their greater maturity and larger human capital at school entry, i.e. higher school readiness, can lead older students to perform better initially. If early learning is complementary to later learning (dynamic complementarities) this initial difference in learning outcomes could place early entrants at a permanent disadvantage.

\subsection{Institutional Framework}

In Spain, children must begin primary school in the September of the calendar year of their 6th birthday. This is an inflexible rule, the birthday cut-off to enter school is January 1st and children are not allowed to postpone entry to school. Although it is not compulsory, almost every child attends kindergarten from the September of the year of their third birthday.

Grade repetition is allowed and common. Students can be obliged to repeat a grade once during primary education (grades 1-6), although some exceptions apply for students with special needs, who can be retained twice. Students can repeat (both) grades 7 and 8; although the total number of repeated years is limited to two in grades 1 to 8 . Grade retention is a common practice in both primary and lower secondary school. In fact, Spain is among the three OECD countries with the highest rates of repetition at the primary level (the others are France and Portugal). Similarly, almost a third of students in lower secondary school repeat at least one grade - in contrast to only $0.5 \%$ of students in Finland (Eurydice, 2011). Thus, grade retention seems to be commonly used as a remedy for pupils in difficulty in primary and lower secondary education.

\section{Data}

We analyze data from five different sources. We use micro data from Spanish birth certificates to study birth seasonality. We rely on data from the OECD Programme for International Student Assessment (PISA) and the Spanish population census to analyse the medium- and long-term impacts of the school entry age, respectively. The PISA data also allows us to look at socioeconomic differences in the effect of being younger at school. 
To analyse the potential mechanisms explaining these socioeconomic differences, we use two different surveys with information about parental investment: the 2009 General Diagnostic Assessment (GDA, Evaluación General de Diagnóstico in Spanish) and the Spanish Time Use Survey (STUS). We use the first of these surveys to study school characteristics and parental help with homework, and the second to study parental time spent on monitoring, teaching and helping children with school-related tasks.

We restrict the analysis of all the datasets to the individuals born in Spain, because seasonality in births (an important element for our identification strategy) can vary across countries.

\subsection{Spanish Birth Certificates}

We use micro data from the universe of Spanish birth certificates from July 2007 to June 2014. The Spanish National Statistical Institute compiles this dataset using the standardized form that families hand in at the time of birth registration. The dataset includes detailed information about the newborn baby (birth weight, method of delivery, gender, an indication of premature birth, among others) and parental demographic characteristics.

We use data starting from 2007 because the information about parental education is only available from that year onwards. We exclude the last semester of 2010 and the first semester of 2011 because Borra, Gonzalez, and Sevilla (2015) show that a temporary policy (a cash transfer) implemented in these years induced changes in birth seasonality. We have 2,462,991 observations in the years included in the analysis and we are left with $2,275,737$ (92\%) after taking into consideration missing values in the variables of interest. Table A.1 reports summary statistics.

\subsection{Programme for International Student Assessment}

PISA is an international survey run by the OECD that assesses the skills and knowledge of 15-year-old students. We use Spanish data from the 2003, 2006, 2009 and 2012 waves to analyse the relationship between age at school entry and academic performance at age 15, and to study how this relationship varies with family background. In addition to test scores in mathematics and language and data on grade repetition, the survey has information on student socioeconomic characteristics: indices of economic, social and cultural status, parental education, and birthday among others. ${ }^{8}$ We obtain a data set with 75,082 observations after pooling the four waves of PISA, from which we keep 74,832 (99.7\%) after dropping observations with missing values. Table A.2 shows the summary

\footnotetext{
${ }^{8}$ PISA 2006, 2009 and 2012 included an optional questionnaire for parents. However, it was not carried out in Spain.
} 
statistics of the sample analysed.

\subsection{Spanish Population Census}

We use micro data from the 2011 Spanish population census. We download the dataset (10\% random sample) from the IPUMS project website, which collects harmonized census data from around the world. We restrict the sample to individuals aged between 30 and 55 at the moment of the census. The database includes information about the individual's education, employment status, marriage status, partner's education (for those married) and month of birth. We obtain a total of 1,437,574 observations and 1,373,194 $(95,5 \%)$ after leaving out observations with missing values. Unfortunately, the census questionnaire does not include questions about parental background. Table A.3 reports summary statistics.

\subsection{General Diagnostic Assessment}

The Spanish Ministry of Education ran the GDA in 2009 with the purpose of evaluating the general competences of students in grade 4. As part of the assessment, a random sample of grade 4 students took standardized tests in 4 subjects (mathematics, reading, science and civic education), while parents, pupils and school principals answered questionnaires. Our outcomes of interest are mainly those related to parental investment in their children's education. We use information from the surveys of students and parents on whether parents help their children with doing homework, check students' homework and attend school meetings. To analyse parental investment through school choice, we use information on school characteristics (public or private school, class size, teacher profile, etc.) from the survey of school principals (who assess how motivated students and parents in the school are).

The dataset includes information on students' birthdays and we use maternal education (an indicator of whether the mother has a college degree) as a proxy for household socioeconomic status. 887 schools were selected to participate in the study, which covered all fourth-grade students in these schools. The GDA dataset contains 21,738 student observations and 18,583 (85.5\%) after taking into account missing responses. Table A.4 shows summary statistics.

\subsection{Spanish Time Use Survey}

We use data from the two waves of the Spanish time use survey (2003 and 2009). Each survey includes a representative sample of the Spanish population. We use information from the diaries of activities reported by all household members older than 10. Each household member older than 10 fills out a diary in which she reports her activities 
across the previous 24 hours, at 10 minute intervals. They also report whether a child aged $0-9$ or another member of the household was present during the activity.

Our outcomes of interest are the time parents spent with their children on the following activities: teaching, reading and playing, and other childcare activities. We construct these variables by adding up the total time that parents report spending on these categories according to their child's age (0 to 9 , and 10 to 17 years old). We also have information on individuals' months of birth and their mothers' education (an indicator of whether the mother has a college education). The sample analysed includes households with children (individuals younger than 18). This amounts to 6,286 households in 2003 and 2,356 in 2009 . We are left with a total sample of 13,045 children (96.8\%) after taking into account missing responses in the variables of interest. Table A.5 shows summary statistics.

\section{Empirical Strategy}

This section presents our empirical approach to analyze how the age at which children begin school affects their performance (at school and also in long-term outcomes), and, more importantly, to study how parents react to this.

\subsection{Month of birth and medium- and long-term outcomes}

We start by providing evidence on the relationship between the month of birth and student outcomes. Using data from PISA, Figure 1 shows local means of grade repetition and test scores at age 15 by month of birth. There is a clear monotonic relationship between these variables. People born later in the year - and hence who are younger at school entry - tend to perform worse at school, both in terms of grade repetition and test scores. The size of the differences in academic performance between the youngest and the oldest children is large. For example, students born in December (the youngest) are around 10 percentage points more likely to have repeated a grade at age 15 than those born in January (the oldest); and to have test scores around 0.1 standard deviations (SD) lower in both mathematics and reading. These differences are similar to the gender gap observed in this dataset.

We then use the population census to look at the relationship between the month of birth and long-term outcomes. Figure 2 shows local means of the probability of having a college degree by month of birth. In contrast to the PISA data, the relationship between the month of birth and schooling is not monotonic. People born around the middle of the year are more likely to have a college education than others, although the magnitude of the differences between months is not large (up to one percentage point). This pattern is difficult to reconcile with a pure age effect - people born in May are younger than people born in January - and suggests the potential existence of seasonality in births. Before 
Figure 1: School Performance in Spain and Month of Birth

A. Students who have repeated at least a grade by age $15(\%)$

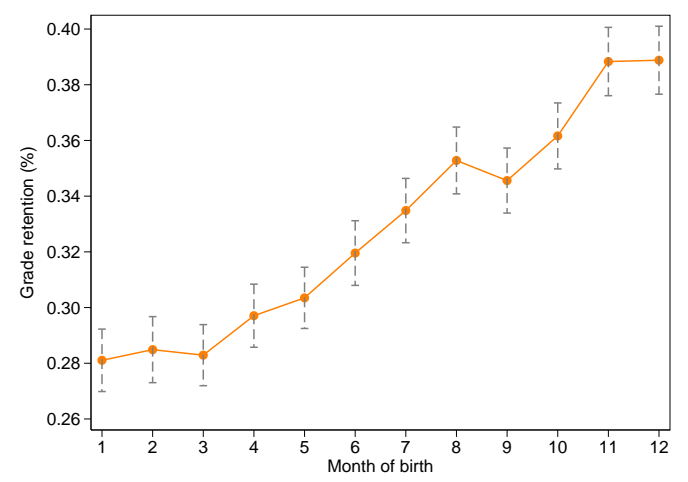

B. Test Scores in mathematics and reading $(\mathrm{SD}=100)$

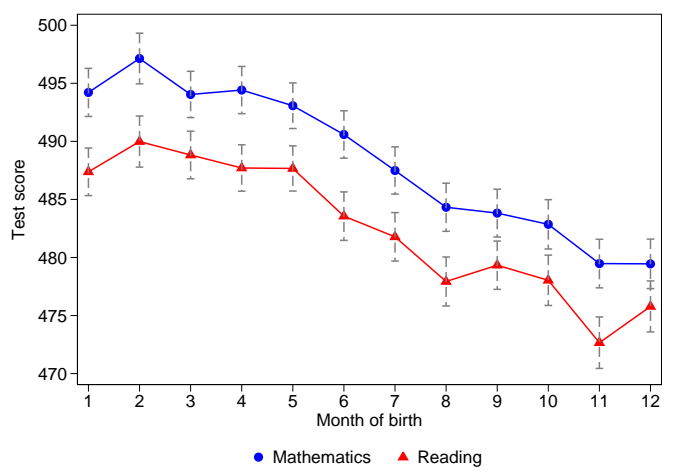

Notes: Data on Spanish students aged 15 assessed in PISA 2003, 2006, 2009 and 2012. The figures plot the share of students who have repeated at least one grade by age 15 and the means of test scores in maths and reading in PISA by month of birth. 95\% confidence intervals are reported.

turning to explore such a pattern, we describe our econometric specification to clarify our discussion about the identification of the causal effect of age at school entry.

Figure 2: Long-term Outcomes: Month of Birth and College Education

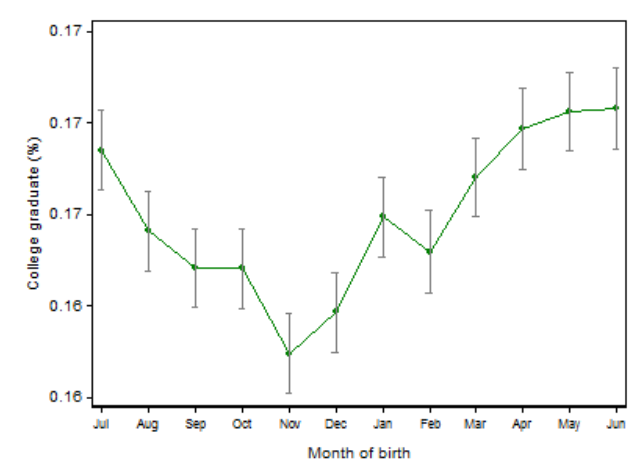

Notes: Data from the 2011 Spanish population census (IPUMS). The sample includes Spanish individuals aged 30 to 55 . The figure plots the share of individuals with a college degree. 95\% confidence intervals are reported.

\subsection{Econometric specification}

Our identification strategy exploits the variation in age at school entry generated by the combination of using a single birthday cut-off (1st of January) to regulate school entry and the fact that children are born throughout the calendar year. This means that children born after the birthday cut-off (e.g. in January) are older at the moment they start school than children born before the cut-off (e.g. in December). With this relationship in mind, we write the following econometric model:

$$
T_{i}=\alpha_{0}+\beta_{1} \text { Young }_{i}+\beta_{2} \text { High SES }_{i}+\beta_{3} \text { Young }_{i} * \text { High SES }+\beta_{k} X_{i}^{\prime}+c_{i}+\epsilon_{i}
$$


where $T_{i}$ is a measure of school performance or effort/time investment made by parents of child $i$, Young $_{i}$ is a normalized scalar that indicates individual $i$ 's month of birth, College mother $r_{i}$ indicates whether individual $i$ 's mother has completed college and $c$ is a vector of birth cohort dummies included when more than one birth cohort is available in the data. The vector $\mathrm{X}^{\prime}$ includes an indicator for whether $i$ is a female and other controls according to the data set used, like the survey year in the case of PISA and STUS, and the date of the interview and household composition for this latter study. The coefficients $\beta_{1}$ and $\beta_{3}$ are the parameters of interest and indicate the effect of school entry age on the outcomes analyzed for individuals with parents from low $\left(\beta_{1}\right)$ and high-SES families $\left(\beta_{1}+\beta_{3}\right)$, proxied by the mother's education.

Interpretation of (differences in) the month of birth as (differences in) the age at school entry depends on parents not manipulating the effective age at which their children start school. In principle, some parents could do this if they are sufficiently concerned about the negative effects associated with the age at school entry. However, this strategy is not feasible in the Spanish context. Schools enforce a strict birthday cut-off for school entry so even if they wish to, parents cannot choose this option. In other words, children's predicted school entry age according to their birthday equals their actual age at school entry in Spain.

Causal interpretation of the coefficients $\beta_{1}$ and $\beta_{3}$ depends on independence between the age at school entry conditional on maternal education and the error term. Broadly, the main threat to identification is that within SES there might be a connection between the month of birth and parental characteristics. This could happen either because some (concerned) parents may plan or postpone births after the birthday cut-off, or, more likely, if mothers with certain characteristics are more likely to give birth in specific months of the year. In this case, the estimated effects of age at school entry would be confounded by birth seasonality. For instance, Buckles and Hungerman (2013) show that in the United States there is such a pattern, as winter births are disproportionally common among teenagers and the unmarried.

Finally, it is worth noticing that we do not include school fixed effects in our specification, unlike other studies on the effects of school entry age on school performance. As we show in Subsection 6.2, school choice is one possible channel through which parents can respond if their children are among the youngest. Therefore, we do not control for school characteristics.

\subsection{Birth seasonality: Maternal and Birth Characteristics}

Ideally, we would like to study birth seasonality using data from the same birth cohorts for which we observe outcomes. Unfortunately, the available data is too recent for such an analysis and we must limit ourselves to studying the cohorts born from the year 2007 
onwards, under the assumption that birth seasonality remains fixed across cohorts. As outlined in the previous subsection, we are primarily concerned about potential seasonality in births according to socioeconomic status (SES). Therefore, we look first at the relationship between the month oh birth and SES (proxied by maternal education).

Figure 3 plots the local means of maternal education (defined as having a college degree) for children born in each month of the year. We centre the graph around the school entry cut-off (January 1st). As we expected from Figure 2, we find suggestive evidence of birth seasonality by socioeconomic status. Children born from April to June tend to have better educated mothers, while those born in August and September tend to have less educated mothers. However, children born in January and December, close to the birthday cut-off for school entry, have on average mothers with similar levels of education (the 95\%-percent confidence intervals of these months overlap). Furthermore, the regression estimate of the difference in average maternal education between the children born in December and January is close to zero (0.002) and is not statistically significant at conventional levels (the standard error is 0.002).

Figure 3: Share of Newborns with College-Educated Mothers by Month of Birth

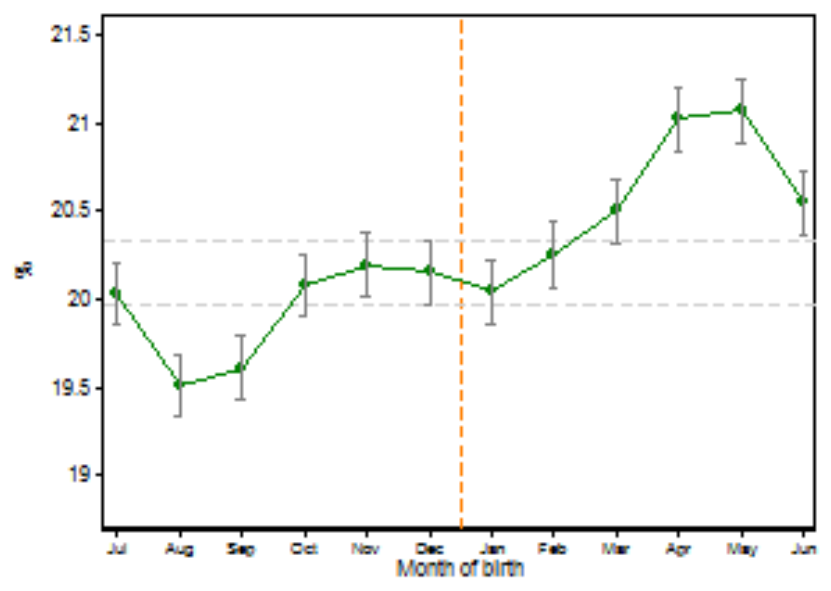

Notes: Data come from Spanish birth certificates. The sample includes the universe of babies born from July 2007 to June 2010 and from July 2011 to June 2014. Local means are represented by dots and 95\% confidence intervals are in gray.

Even if there is no observable connection between maternal SES and the month of birth close to the birthday cut-off for school entry, it is possible that there is a relationship between newborn characteristics and the month of birth within SES if parental characteristics or environmental (institutional) conditions vary by month. To study this possibility, Figure 4 displays the means of several birth characteristics (low weight, premature birth and delivery by c-section) of children born in each month from mothers with (Panel A) and without (Panel B) a college degree. In line with Figures 2 and 3, being born around 
the middle of the year is associated with more positive outcomes. However, the birth characteristics of children born around the birthday cut-off for school entry seem to be similar both for children from college and non-college-educated mothers. We confirm this pattern with Table 1, in which we report precisely estimated zeroes for the differences in monthly means by SES of birth characteristics of children born in December and January. Therefore, from now on we focus our analysis on children born in December and January.

Figure 4: New-born Characteristics and Month of Birth

\section{A. Children of non-college-educated mothers}

Low birth weight

Premature
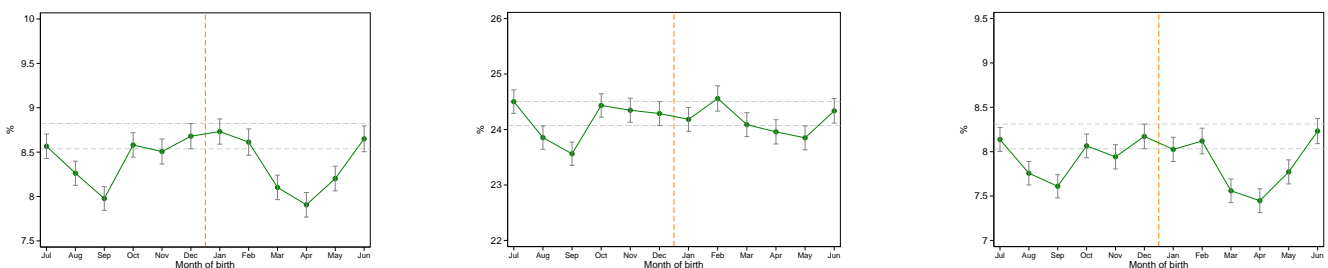

B. Children of college educated mothers

Low birth weight

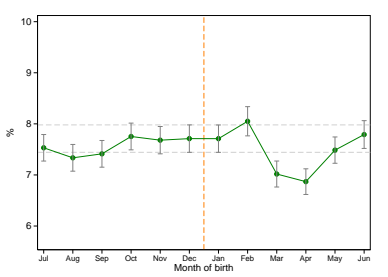

C-Section

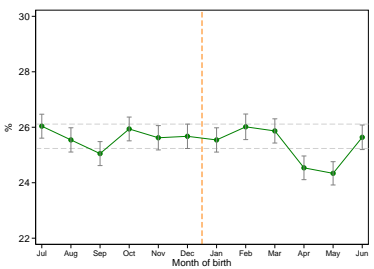

Premature

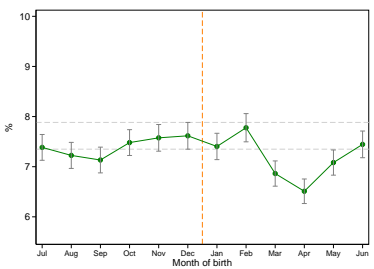

Notes: Data from Spanish birth certificates. The sample includes the universe of Spanish babies born from non-college graduate mothers (first three figures) or from college educated mothers (last three figures) in the period from July 2007 to June 2010 and from July 2011 to June 2014.. The figures plot, by month of birth, the percentage of newborns with a low birth weight, the percentage of babies born by cesarean, and the percentage of premature babies. The means are represented by dots and $95 \%$ confidence intervals are in gray. 
Table 1: Birth Characteristics: Children born in January vs December by SES

\begin{tabular}{lcccccc}
\hline \hline & \multicolumn{2}{c}{ Children of non-college mothers } & \multicolumn{2}{c}{ Children of college educated mothers } \\
\hline & December & \multicolumn{2}{c}{ December vs. January } & \multicolumn{2}{c}{ December } & \multicolumn{2}{c}{ December vs. January } \\
\cline { 2 - 7 } & Mean & Difference of means & SE & Mean & Difference of means & SE \\
\cline { 2 - 7 } & 0.0873 & -0.001 & $(0.001)$ & 0.0771 & -0.000 & $(0.002)$ \\
Low-weight $(<2500$ grams $)$ & 0.0803 & 0.002 & $(0.001)$ & 0.0740 & 0.002 & $(0.002)$ \\
Premature & 0.242 & 0.001 & $(0.002)$ & 0.255 & 0.002 & $(0.003)$ \\
C-section & & 5.88 & {$[0.1178]$} & & 2.07 & {$[0.5576]$} \\
$\chi^{2}\left[\right.$ Prob $\left.>\chi^{2}\right]$ & 302,523 & & & 76,101 & & \\
Observations & & & & \\
\hline \hline
\end{tabular}

Notes: Data from Spanish birth certificates, period 2007-2014 (except December 2010 and January 2011). The sample includes Spanish individuals born in December and January. First 3 columns show the results for the sample of babies of non-college mothers and the last 3 columns for the sample of babies born

from mothers with a college degree. Standard errors are in parentheses. ${ }^{* * *} \mathrm{p}<0.01,{ }^{* *} \mathrm{p}<0.05,{ }^{*} \mathrm{p}<0.1$. 


\section{The Effect of Being the Youngest}

In this section, we present the reduced-form effects of age at school entry on student and adult outcomes. Our main specification only includes individuals born in January or December to avoid problems related to birth seasonality in children and maternal characteristics. First, we examine the average effects on medium- and long-term outcomes, using data from PISA and Spanish population census, respectively. Then, in Subsection 5.2 , we analyze whether these effects vary by socioeconomic status.

\subsection{Poor Little Children: Short and Long-Term Effects of Being the Youngest}

Columns 1-3 in Table 2 present the results of regressing several measures of school performance (grade retention, maths and reading test scores) on an indicator of whether the student was born in December or in January, an indicator for being a female and an indicator for coming from a family with a high socioeconomic status (in the top $25 \%$ of the distribution of the SES index). All the regressions include vectors of dummies for the year of birth and the PISA survey year. Remember that the oldest children in a class are born in January $(Y$ oung $=0)$ and the youngest children are born in December $($ Young $=1)$.

Along the same line as the visual evidence, younger students do worse in school than their older peers. The youngest children in their cohort are 10 percentage points more likely to have repeated a grade at age 15 than the oldest children (Column 1). This gap is similar to the gender gap in grade retention (see row 2, also in Column 1), and around $2 / 5$ of the estimated gap for socioeconomic status (see row 3 ). In the same fashion, there is a clear age gap in student achievement as measured by standardized test scores. On average, the youngest students have lower test scores in mathematics (-0.14 SD) and in reading $(-0.11 \mathrm{SD})$. All the results discussed are statistically significant at the one percent level.

Columns 4-6, also in Table 2, present the results for the long-term effects of being an early entrant to school using data from the Spanish population census. The sample analysed includes individuals born in December and January. We do not include information on parental SES because we do not observe this information in the census data. All the regressions include birth cohort dummies. Note that the birth cohorts here are defined to compare individuals born in adjacent months (we cannot do this for the PISA data because we would compare students in different grades). We find that people born in January (the oldest at school entry) are more likely to have a college degree (by 0.6 percentage points) and to have a more educated partner (one with a college degree, by 0.7 
percentage points) than people born in December (the youngest at school entry). Both results are statistically significant at the 1 one percent level. We do not find statistically significant differences in the probability of being employed. Summing up, Table 2 documents that - in line with the international literature - people who are younger at school entry tend to have worse student outcomes, which seems to translate into the long term. We now move on to analyse differences by parental SES.

Table 2: Medium- and long-term outcomes

\begin{tabular}{|c|c|c|c|c|c|c|}
\hline & \multicolumn{3}{|c|}{ Medium-term outcomes } & \multicolumn{3}{|c|}{ Long-term outcomes } \\
\hline & $\begin{array}{c}\text { Grade } \\
\text { retention } \\
\quad(1)\end{array}$ & $\begin{array}{c}\text { Maths } \\
\text { score } \\
(2)\end{array}$ & $\begin{array}{c}\text { Reading } \\
\text { score } \\
(3)\end{array}$ & $\begin{array}{l}\text { College } \\
\text { graduate } \\
(4)\end{array}$ & $\begin{array}{c}\text { Employed } \\
\text { (5) }\end{array}$ & $\begin{array}{c}\text { Partner has } \\
\text { college degree } \\
(6)\end{array}$ \\
\hline Young & $\begin{array}{c}0.105^{* * *} \\
(0.008)\end{array}$ & $\begin{array}{c}-13.861^{* * *} \\
(1.440)\end{array}$ & $\begin{array}{c}-11.164^{* * *} \\
(1.433)\end{array}$ & $\begin{array}{c}-0.00599^{* * *} \\
(0.00198)\end{array}$ & $\begin{array}{c}0.00152 \\
(0.00247)\end{array}$ & $\begin{array}{c}-0.00729^{* * *} \\
(0.00216)\end{array}$ \\
\hline Female & $\begin{array}{c}-0.086^{* * *} \\
(0.008)\end{array}$ & $\begin{array}{c}-11.568^{* * *} \\
(1.440)\end{array}$ & $\begin{array}{c}34.421^{* * *} \\
(1.433)\end{array}$ & $\begin{array}{c}0.0281^{* * *} \\
(0.00195)\end{array}$ & $\begin{array}{l}-0.125^{* * *} \\
(0.00243)\end{array}$ & $\begin{array}{c}-0.00791^{* * *} \\
(0.00211)\end{array}$ \\
\hline Top $25 \%$ SES & $\begin{array}{c}-0.259^{* * *} \\
(0.009)\end{array}$ & $\begin{array}{c}59.506^{* * *} \\
(1.654)\end{array}$ & $\begin{array}{c}53.436^{* * *} \\
(1.646)\end{array}$ & & & \\
\hline Mean & 0.28 & 499.25 & 491.24 & 0.143 & 0.680 & 0.119 \\
\hline Observations & 12,311 & 12,311 & 12,311 & 226,454 & 226,454 & 162,920 \\
\hline
\end{tabular}

Notes: The data analysed in columns 1 to 3 come from Spanish students aged 15 assessed in PISA 2003, 2006, 2009 and 2012. In these first three columns the outcome variables are indicators of school performance. Grade retention (Column 1) indicates whether the student repeated a grade at least once, and maths and reading scores (columns 2 and 3) represent the student's performance in the PISA tests. The data analysed in columns 4 to 6 come from the 2011 Spanish population census. In Column 4 , the outcome variable is an indicator of whether the individual is a college graduate, in Column 5 it is an indicator of whether s/he is employed, and in Column 6 an indicator of whether her/his spouse is a college graduate. The sample includes Spanish individuals born in December and January. "Young" is an indicator variable that equals one if the student was born in December and equals zero if $\mathrm{s} /$ he was born in January. The regressions presented in columns 1 to 3 include year of birth dummies and those presented in columns 4 to 6 include cohort dummies, where the cohorts are defined as being born from July to June of the following year. Robust standard errors are in parentheses. ${ }^{*} \mathrm{p}<0.10,{ }^{* *} \mathrm{p}<0.05$, $* * * \mathrm{p}<0.01$.

\subsection{Socioeconomic Status and the Disadvantages of Being Younger: Poor (Poor) Little Children}

Table 3 shows the results of regressing measures of student performance on an indicator of whether the student was born in December or January, an indicator for being a female, an indicator for coming from a family in the top $25 \%$ of the distribution of the SES index, and an interaction term between these two indicators (Young * top 25\%). 
Table 3: School performance, entry age and socioeconomic status

\begin{tabular}{lccc}
\hline \hline & $\begin{array}{c}\text { Grade retention } \\
(1)\end{array}$ & $\begin{array}{c}\text { Maths score } \\
(2)\end{array}$ & $\begin{array}{c}\text { Reading score } \\
(3)\end{array}$ \\
& & & \\
\hline Young & $0.127^{* * *}$ & $-16.439^{* * *}$ & $-13.754^{* * *}$ \\
& $(0.009)$ & $(1.666)$ & $(1.658)$ \\
Female & $-0.086^{* * *}$ & $-11.553^{* * *}$ & $34.435^{* * *}$ \\
& $(0.008)$ & $(1.440)$ & $(1.432)$ \\
Top 25\% SES & $-0.215^{* * *}$ & $54.408^{* * *}$ & $48.317^{* * *}$ \\
& $(0.013)$ & $(2.343)$ & $(2.331)$ \\
Young * top 25\% SES & $-0.087^{* * *}$ & $10.153^{* * *}$ & $10.195^{* * *}$ \\
& $(0.019)$ & $(3.306)$ & $(3.289)$ \\
Mean & & & \\
\hline Observations & 0.28 & 499.25 & 491.24 \\
\hline \hline
\end{tabular}

Notes: Data from Spanish students aged 15 assessed in PISA 2003, 2006, 2009 and 2012. The outcome variables are indicators of school performance. Grade retention (Column 1) indicates whether the student repeated a grade at least once, and maths and reading scores (columns 2 and 3) represent the student's performance in the PISA tests. "Young" is an indicator variable that equals one if the student was born in December and equals zero if s/he was born in January. All regressions include year dummies as controls. Robust standard errors are in parentheses. ${ }^{*} \mathrm{p}<0.10,{ }^{* *} \mathrm{p}<0.05,{ }^{* * *}$ $\mathrm{p}<0.01$.

We find clear differences in the effect of age at school entry by socioeconomic background. Being young is significantly worse for the poor. Young students from a low socioeconomic background are 12.7 percentage points more likely to have repeated a grade at age 15 than older students from the same socioeconomic background (see row 1 in Column 1). However, this age effect is significantly smaller for children with a high socioeconomic background, by 8.7 percentage points. A qualitatively similar argument can be made about achievement at age 15, as measured by test scores in maths and reading. Young students from a low socioeconomic background have -0.16 SD (-0.14 SD) lower maths (reading) test scores than their older counterparts (see row 1 in columns 2-3), while this age effect is significantly smaller for privileged children: $0.1 \mathrm{SD}$ in both subjects. These results are statistically significant at the one percent level. ${ }^{9}$

Therefore, families with a high socioeconomic status seem to buffer the negative effect of being relatively young on their children's outcomes, while those with a lower socioeconomic background do not. In Section 6 we discuss two potential mechanisms behind this result and analyse data on parental involvement in their children's education to study whether parents respond differently to age at school entry depending on their SES.

\footnotetext{
${ }^{9}$ We find similar results when using the Index of SES as a continuous variable. See Figure B.1 in the online Appendix.
} 


\section{Parental Responses}

Two channels could explain why entry age effects are greater among children from lowSES families. First, high-SES children might actually be ready to start school irrespective of their age. Note that high-SES children are likely to be more ready to start school than low-SES children, because of the well-established correlation between family SES and preschool investment. This explanation implies that what puts young children at a learning disadvantage is being below a minimum level of achievement (maturity) on the first day of school and that growing up in a more nurturing environment makes it more likely that even the youngest children are above this minimum level.

Second, high-SES parents might increase their investment when their children are among the youngest at school entry to compensate for their learning disadvantage. Parents with higher SES are likely to be more prepared in terms of financial resources, human capital and information to invest in their children in reaction to a negative shock. A dominance of channel one implies that among high-SES families one should not observe differences in parental investment according to the child's age at school entry. A dominance of channel two implies the opposite. In this section, we analyze data on parental involvement in their children's education to study whether parents respond differently to age at school entry depending on their SES.

We begin the study of parental time investment by using data from the Spanish Time Use Survey (STUS) and the General Diagnostic Assessment survey (GDA). Then, using the second of these surveys, we analyze whether parents choose schools with different inputs when their children are younger at school entry. Finally, we investigate whether parental responses vary according to the age and the gender of children.

\subsection{Parental Time Investment}

Our main estimates on parental time investment come from data from the two waves of the Spanish time use surveys. The STUS reports detailed use of the time that parents spend participating in activities directly related to their children's human capital development.

Table 4 reports the estimated coefficients from Equation 1 using as outcomes measures of the time (in minutes) that parents spend teaching their children, reading and playing with them, and on other childcare activities. These coefficients represent the effects of age at school entrance on parental time investments and how such effects interact with family socioeconomic status (i.e. whether the mother has a college education or not).

In households with non-college-educated mothers, the school entry age does not seem to affect parental time investment in activities related to children's human capital development. The coefficient for being the youngest in the three regressions presented has a small magnitude and is not statistically significant at conventional levels. In contrast, 
households with university-educated mothers do spend significantly more time with their children on activities related to teaching $(+5$ minutes per day, significant at the five percent level) than their older peers from similar types of families. There are not statistically significant differences according to children's month of birth in the time that highly educated parents spend on the other childcare activities. Thus, more educated parents compensate by investing more time in teaching activities when their children are among the youngest in their school cohort. Interestingly, this effect seems to be larger during the school months (see Table B.4 in the online Appendix).

Table 4: Parental Time investment

\begin{tabular}{lccc}
\hline \hline & $(1)$ & $(2)$ & $(3)$ \\
& Teaching & Reading and Playing & Other childcare activities \\
\hline Youngest & -0.145 & 0.798 & -3.135 \\
& $(1.155)$ & $(2.466)$ & $(6.007)$ \\
College mother & 1.103 & $13.55^{* * *}$ & $35.93^{* * *}$ \\
& $(1.511)$ & $(3.560)$ & $(8.641)$ \\
Youngest X College Mother & $5.052^{* *}$ & -1.554 & -1.151 \\
& $(2.560)$ & $(4.670)$ & $(11.22)$ \\
\hline Observations & 2196 & 2196 & 2196 \\
\hline \hline
\end{tabular}

Notes: Data from the Spanish Time Use Survey 2003 and 2009. The sample consists of children aged 0 to 17 born in December or January in Spain. The outcome variables indicate the minutes parents spent daily with their children doing different activities: ones related to teaching (Column 1), reading and playing (Column 2), and other childcare activities (Column 3). "Young" is an indicator variable that equals one if the student was born in December and equals zero if she was born in January. The variable "college mother" takes value 1 if the mother of the student has a college degree and zero otherwise. All the reported models include a vector of dummies for birth cohort, and quarter and day of interview. Standard errors are clustered at the household level. ${ }^{* * *} \mathrm{p}<0.01,{ }^{* *} \mathrm{p}<0.05,{ }^{*} \mathrm{p}<0.1$

We complement these results with data from the General Diagnostic Assessment survey. Here, using self-reported statements, we analyze whether parents respond to school entry age by changing their behaviour regarding helping children with their homework, checking their homework, or by attending school meetings more frequently (as reported by the students). As before, we examine whether the parental responses depend on maternal education.

Table 5 presents the estimated coefficients from Equation 1 in which the outcome variables are indicators of different dimensions of parental involvement. As in the time use data, we do not find that households with non-college educated mothers invest differently if their children enter school at a younger age (first row of Column 1); and, we do find differences in households with college-educated mothers. Children from universityeducated mothers are significantly more likely to receive help to do their homework (+ 8 percentage points, significant at the 1 percent level) and to have their parents check their homework $(+7.6$ percentage points, significant at the five percent level) than their older peers from similar types of family (see the coefficient for the interaction Young* College mother in columns 1 and 2). It also seems more likely that their parents go to 
school meetings, although the effect is imprecisely estimated (Column 3). Summing up, this evidence shows that more educated parents compensate for school disadvantage by putting more effort into helping their children with their with academic tasks..

Table 5: Parental Involvement

\begin{tabular}{lccc}
\hline \hline & $(1)$ & $(2)$ & $(3)$ \\
& Help with homework & Parents check homework & Parents go to school meetings \\
\hline Youngest & 0.00447 & 0.00354 & -0.0228 \\
& $(0.0154)$ & $(0.0190)$ & $(0.0201)$ \\
College mother & $0.0349^{*}$ & $-0.108^{* * *}$ & -0.0267 \\
& $(0.0192)$ & $(0.0271)$ & $(0.0275)$ \\
Youngest X College mother & $0.0750^{* * *}$ & $0.0724^{* *}$ & 0.0425 \\
& $(0.0247)$ & $(0.0364)$ & $-0.0377)$ \\
Girl & -0.0152 & $0.0327^{* *}$ & $(0.0169)$ \\
& $(0.0123)$ & $(0.0166)$ & 3345 \\
\hline Observations & 3461 & 3350 & Span \\
\hline \hline
\end{tabular}

Notes: The data comes from the General Diagnostic Assessment survey of 2009. The sample includes Spanish students enrolled in 4th grade who were born in December or in January. The outcome variables are different measures of parental involvement in children's education: a variable indicating whether parents help their children with the homework (Column 1), an indicator variable of parents checking children's homework (Column 2), and a variable indicating whether parents frequently go to school meetings (Column 3). "Young" is an indicator variable that equals one if the student was born in December and equals zero if she was born in January. The variable "college mother" takes value 1 if the mother of the student has a college degree and zero otherwise. Standard errors are clustered at the school level. ${ }^{*} \mathrm{p}<0.10,{ }^{* *} \mathrm{p}<0.05,{ }^{* * *} \mathrm{p}<0.01$

\subsection{School Choice}

We now analyse whether parents respond to school entry age by sending their children to schools with different levels of inputs, and whether these reactions vary according to the level of maternal education.

Using the General Diagnostic Assessment, we look at differences in several school inputs between the schools that students born in December and January attend. To do this, we rely on the principal and teacher survey questionnaires. Table 6 presents the coefficient estimates from Equation 1. In the first column, the outcome is an indicator variable of whether the student attends a concertada school: a privately-managed school, which may offer a more customized education environment than regular schools. We do not find that entry age significantly affects school choice regarding this specific feature, independently of the mother's education. However, younger children with college-educated mothers are more likely to attend schools with smaller class sizes (- 0.6 students, significant at the 10 percent level), more motivated peers $(+7$ percentage points, significant at the five percent level), with better teachers $(+0.1 \mathrm{SD}$ in a teacher quality index significant at the five percent level) and with parents more involved in the school $(+0.1$ $\mathrm{SD}$ in a parental involvement index, significant at the five percent level) than their older 
peers from similar types of families. In contrast, we do not observe significant differences in the characteristics of the schools attended by children from mothers without a college education (see the first row in columns 1-4). In the online Appendix we provide the disaggregated effects of the variables that constitute the Teacher Quality and the Parental Involvement indexes, plus a School Quality Index, which aggregates the nine variables analysed (which shows results consistent with those presented in Table 6). Therefore, we find that more educated parents are more likely to send their children to schools with better inputs when they enter school at an earlier age. ${ }^{10}$

Overall, these results are consistent with the idea that more educated parents compensate when their children start school at an earlier age by spending more time helping their children with school and sending their children to schools with better inputs. Along the same lines, we do not find that less educated parents change their patterns of investment in their children to compensate for or reinforce the effects of entry age. This socioeconomic difference in compensating behaviour helps to explain why the detrimental effect of being young at school entry is greater for low-SES children. ${ }^{11}$

Table 6: School Quality

\begin{tabular}{lccccc}
\hline \hline & $\begin{array}{c}(1) \\
\text { Concertada } \\
\text { school }\end{array}$ & $\begin{array}{c}\text { Class } \\
\text { size }\end{array}$ & $\begin{array}{c}\text { Peers motivated } \\
\text { to learn }\end{array}$ & $\begin{array}{c}(4) \\
\text { Teacher } \\
\text { quality index }\end{array}$ & $\begin{array}{c}(5) \\
\text { Parental } \\
\text { involvement index }\end{array}$ \\
\hline Youngest & 0.00284 & 0.214 & -0.0256 & -0.00598 & -0.00791 \\
College mother & $(0.0204)$ & $(0.179)$ & $(0.0214)$ & $(0.0244)$ & $(0.0304)$ \\
& $0.232^{* * *}$ & $1.325^{* * *}$ & $0.138^{* * *}$ & 0.00358 & -0.00558 \\
Youngest X College mother & $(0.0299)$ & $(0.289)$ & $(0.0271)$ & $(0.0319)$ & $(0.0417)$ \\
Girl & 0.0361 & $-0.576^{*}$ & $0.0669^{* *}$ & $0.0984^{* *}$ & $0.0960^{* *}$ \\
& $(0.0370)$ & $(0.338)$ & $(0.0332)$ & $(0.0431)$ & $(0.0485)$ \\
\hline Observations & 0.0164 & 0.136 & -0.00876 & 0.00822 & 0.00959 \\
\hline \hline
\end{tabular}

Notes: The data come from the General Diagnostic Assessment survey 2009. The sample includes Spanish students enrolled in grade 4 who were born in December or January. The outcome variables are different school characteristics: a concertada school indicator (Column 1), class size (Column 2), an indicator of whether the teacher reports that the students in her class are very motivated (Column 3), a Teacher Quality Index (Column 4) and a Parental Involvement Index (Column 5) "Young" is an indicator variable that equals one if the student was born in December and equals zero if she was born in January. The variable "college mother" takes value 1 if the mother of the student has a college degree and zero otherwise. Standard errors are clustered at the school level. $* \mathrm{p}<0.10, * * \mathrm{p}<0.05, * * * \mathrm{p}<0.01$

\footnotetext{
${ }^{10}$ Also in the General Diagnostic Assessment, both parents and students declare (in separate surveys) if the student is enrolled in her current school because she lives in the school's catchment area. We use this information as an indicator that parents choose (or not) to send their young children to different schools from the default option. We find that children from mothers without a college education seem to go to their neighborhood school regardless of the month when they were born, while young children from college-educated mothers seem to be more likely to attend a different school to the default option than the older children from similarly educated mothers. Table B.1 in the online Appendix reports the results.

${ }^{11}$ To investigate how parents react when one compensation channel (school choice) is less available, we split the sample into large and small localities (with above/below 50,000 inhabitants). In large localities, we find that high-SES parents compensate both in terms of involvement and school choice. In small localities, we do not find that high-SES parents are more likely to send their younger children to a school with better inputs (as expected), although a larger proportion help their children with homework. The results are available from the authors on request.
} 


\subsection{Heterogeneity Analysis}

\subsubsection{Parental Time Investment according to Age}

Using data from the Time Use survey, Table 7 reports the estimated coefficients from Equation 1 for three age groups: children younger than 6 (who are below school age at the moment of the survey), children aged 6 to 12 (who are of primary school age), and children aged 13 to 17 (who are of secondary school age). Table 4 shows that young children with highly educated mothers spend more time with their parents on activities related to teaching than their older peers. If these results are driven by a mere age effect and not by what is going on in school (i.e. not by a negative early entry age effect), we might expect a similar pattern if we analyse the sample of children who are outside of compulsory school age. However, as shown in Table 7 (row 3 in columns 1-3), the coefficient for the interaction Young*College Mother is not significantly different from zero when estimated using the sample of children aged 0 to 5 . In contrast, the coefficient for this interaction is positive and statistically significant when we analyse the sample of children who are above school entry age, i.e. aged 6 to 12 (Column 4) and 13 to 17 (Column 7).

Interestingly, the magnitude of the point estimate in the sample of children aged 6 to 12 seems to be larger than that in the sample of children aged 13 to 17 . While in the former sample the youngest children from households with university-educated mothers spend 10 minutes more a day with their parents on activities related to teaching than their older peers, in the latter sample the corresponding figure amounts to only 7 minutes. This pattern is consistent with the ideas that 1) parents react to their realization that their child has a school disadvantage, and 2) that the returns on investments at earlier ages are larger. This is only suggestive evidence as we do not have enough statistical precision to rule out that both parameters are of the same magnitude. As Table B.4 in the online Appendix shows, the compensating effect becomes larger when we exclude the summer months, which reinforces the idea that parental reactions are driven by what is going on in school. Once more, across the three age groups we observe that in households with more lowly educated mothers entry age does not seem to affect parental time investment in activities related to children's human capital development. 
Table 7: Parental Time Investment by Age Groups

\begin{tabular}{|c|c|c|c|c|c|c|c|c|c|}
\hline & $\begin{array}{c}(1) \\
\text { Teaching }\end{array}$ & $\begin{array}{c}(2) \\
\text { Reading and Playing } \\
0-5\end{array}$ & $\begin{array}{c}\text { (3) } \\
\text { Other childcare }\end{array}$ & $\begin{array}{c}(4) \\
\text { Teaching } \\
\end{array}$ & $\begin{array}{c}(5) \\
\text { Reading and Playing } \\
6-12\end{array}$ & $\begin{array}{c}(6) \\
\text { Other childcare }\end{array}$ & $\begin{array}{c}(7) \\
\text { Teaching } \\
\end{array}$ & $\begin{array}{c}(8) \\
\text { Reading and Playing } \\
13-17\end{array}$ & $\begin{array}{c}(9) \\
\text { Other childcare }\end{array}$ \\
\hline Youngest & $\begin{array}{l}-0.370 \\
(1.649)\end{array}$ & $\begin{array}{c}6.503 \\
(6.925)\end{array}$ & $\begin{array}{c}2.857 \\
(13.76)\end{array}$ & $\begin{array}{l}-0.564 \\
(2.389)\end{array}$ & $\begin{array}{c}0.655 \\
(3.468)\end{array}$ & $\begin{array}{c}10.68 \\
(7.357)\end{array}$ & $\begin{array}{c}-0.762 \\
(1.679)\end{array}$ & $\begin{array}{c}2.013 \\
(1.889)\end{array}$ & $\begin{array}{c}-2.299 \\
(4.223)\end{array}$ \\
\hline College mother & $\begin{array}{c}1.642 \\
(2.173)\end{array}$ & $\begin{array}{c}16.19^{* *} \\
(7.169)\end{array}$ & $\begin{array}{c}34.07^{* *} \\
(15.49)\end{array}$ & $\begin{array}{c}1.288 \\
(3.088)\end{array}$ & $\begin{array}{l}7.809^{*} \\
(4.188)\end{array}$ & $\begin{array}{c}16.27 \\
(10.21)\end{array}$ & $\begin{array}{c}0.198 \\
(2.212)\end{array}$ & $\begin{array}{l}-0.977 \\
(1.626)\end{array}$ & $\begin{array}{l}-3.883 \\
(4.117)\end{array}$ \\
\hline Youngest X College Mother & $\begin{array}{l}-1.957 \\
(2.983)\end{array}$ & $\begin{array}{l}-12.20 \\
(10.01)\end{array}$ & $\begin{array}{l}-12.43 \\
(21.46)\end{array}$ & $\begin{array}{l}10.63^{* *} \\
(5.334)\end{array}$ & $\begin{array}{c}4.451 \\
(6.422)\end{array}$ & $\begin{array}{l}-4.026 \\
(13.36)\end{array}$ & $\begin{array}{l}7.726^{*} \\
(4.676)\end{array}$ & $\begin{array}{c}1.025 \\
(3.161)\end{array}$ & $\begin{array}{c}8.041 \\
(6.364)\end{array}$ \\
\hline Girl & $\begin{array}{c}0.704 \\
(1.466)\end{array}$ & $\begin{array}{l}-2.962 \\
(5.263)\end{array}$ & $\begin{array}{l}-12.10 \\
(10.18)\end{array}$ & $\begin{array}{l}-0.892 \\
(2.165)\end{array}$ & $\begin{array}{l}0.0376 \\
(2.876)\end{array}$ & $\begin{array}{l}-6.112 \\
(6.090)\end{array}$ & $\begin{array}{l}1.736 \\
(1.593)\end{array}$ & $\begin{array}{c}-3.075^{* *} \\
(1.560)\end{array}$ & $\begin{array}{l}-3.574 \\
(3.327)\end{array}$ \\
\hline Observations & 744 & 744 & 744 & 812 & 812 & 812 & 640 & 640 & 640 \\
\hline
\end{tabular}

Notes: Data from the Spanish Time Use Survey 2003 and 2009. The sample is of children aged 0 to 17 born in December or January in Spain. The first 3 columns include only children younger than 6 , columns 4 to 6 include children aged 6 to 12 and the last 3 columns include children aged 13 to 17 . The outcome variables indicate the minutes a day parents spent with their children doing different activities: ones related to teaching, to reading mother of the student has a college degree and zero otherwise. All the reported models include a vector of dummies for birth cohort, and quarter and day of interview. Standard errors are clustered at the household level. ${ }^{* * *} \mathrm{p}<0.01,{ }^{* *} \mathrm{p}<0.05,{ }^{*} \mathrm{p}<0.1$ 


\subsubsection{Gender Differences}

Finally, we analyse whether the responses from highly- and poorly-educated parents vary according to the student's gender. To do this, we first analyze whether the age effect on student outcomes, as measured by PISA, differs with gender. We find some evidence, which is reported in Table 8, that this is the case. As before, we observe that being among the youngest at school entry has a significant negative effect among children from low-SES families, both for boys and girls (see row 1, columns 1-6). However, the story seems to be different for children from high-SES families. It is less clear whether boys from high-SES families manage to overcome the age disadvantage (see row 3, columns 13). The coefficient for grade repetition is statistically significant at the five percent level, while the coefficient for the maths test score is not statistically significant at conventional levels and the one for the Spanish score is statistically significant at the ten percent level. In contrast, we do not observe a gap in student outcomes among high-SES girls. The magnitude of the coefficients reported in row 3, columns 4-6 resembles that of those in row 1, columns 4-6. Therefore, at age 15, there are no differences in academic performance between December- and January-born girls who come from advantaged families.

Table 8: School Performance by Student Gender

\begin{tabular}{|c|c|c|c|c|c|c|}
\hline & \multicolumn{3}{|c|}{ Boys } & \multicolumn{3}{|c|}{ Girls } \\
\hline & $(1)$ & $(2)$ & $(3)$ & $(4)$ & $(5)$ & $(6)$ \\
\hline & Grade retention & Maths score & Reading score & Grade retention & Maths score & Reading score \\
\hline \multirow[t]{2}{*}{ Young } & $0.135^{* * *}$ & $-17.197^{* * *}$ & $-16.526^{* * *}$ & $0.118^{* * *}$ & $-15.686^{* * *}$ & $-11.031^{* * *}$ \\
\hline & $(0.014)$ & $(2.448)$ & $(2.492)$ & $(0.013)$ & $(2.264)$ & $(2.192)$ \\
\hline \multirow{2}{*}{ Top $25 \%$ SES } & $-0.231^{* * *}$ & $55.298 * * *$ & $50.989^{* * *}$ & $-0.198^{* * *}$ & $53.294^{* * *}$ & $45.409 * * *$ \\
\hline & $(0.019)$ & $(3.395)$ & $(3.456)$ & $(0.018)$ & $(3.230)$ & $(3.127)$ \\
\hline \multirow{2}{*}{ Young * top 25\% SES } & $-0.061^{* *}$ & 6.599 & $8.930^{*}$ & $-0.115^{* * *}$ & $14.187^{* * *}$ & $11.777^{* * *}$ \\
\hline & $(0.027)$ & $(4.790)$ & $(4.877)$ & $(0.026)$ & $(4.557)$ & $(4.412)$ \\
\hline Observations & 6070 & 6070 & 6070 & 6241 & 6241 & 6241 \\
\hline
\end{tabular}

Using the Spanish time use surveys, Table 9 shows that young boys from households with university-educated mothers spend significantly more time with their parents on activities related to teaching ( +15 minutes every day) than their older male peers from similar types of families. There are no significant differences in the responses on parental time investment in the case of boys in households with poorly-educated mothers. In the case of girls, the coefficient for Young * College mother is not statistically significant in any of the three regressions (columns 4 to 6 ). However, both highly- and poorly-educated parents devote more non-educational time to girls when they are among the youngest in their class (Column 6). 
Table 9: Parental Time Investment by Student Gender

\begin{tabular}{|c|c|c|c|c|c|c|}
\hline & \multicolumn{3}{|c|}{ Boys } & \multicolumn{3}{|c|}{ Girls } \\
\hline & $\begin{array}{c}(1) \\
\text { Teaching }\end{array}$ & $\begin{array}{c}(2) \\
\text { Reading and Playing }\end{array}$ & $\begin{array}{c}(3) \\
\text { Other childcare }\end{array}$ & $\begin{array}{c}(4) \\
\text { Teaching }\end{array}$ & $\begin{array}{c}(5) \\
\text { Reading and Playing }\end{array}$ & $\begin{array}{c}(6) \\
\text { Other childcare }\end{array}$ \\
\hline Youngest & $\begin{array}{l}-1.201 \\
(2.225)\end{array}$ & $\begin{array}{l}-0.832 \\
(3.156)\end{array}$ & $\begin{array}{l}-3.082 \\
(7.176)\end{array}$ & $\begin{array}{c}0.512 \\
(1.989)\end{array}$ & $\begin{array}{l}4.500^{*} \\
(2.662)\end{array}$ & $\begin{array}{c}17.00^{* * *} \\
(5.949)\end{array}$ \\
\hline College mother & $\begin{array}{l}-2.657 \\
(2.442)\end{array}$ & $\begin{array}{c}4.850 \\
(3.979)\end{array}$ & $\begin{array}{c}3.360 \\
(8.966)\end{array}$ & $\begin{array}{l}5.227^{*} \\
(3.040)\end{array}$ & $\begin{array}{c}4.568 \\
(3.002)\end{array}$ & $\begin{array}{l}17.02^{*} \\
(8.916)\end{array}$ \\
\hline Youngest X College Mother & $\begin{array}{c}14.70^{* * *} \\
(5.430)\end{array}$ & $\begin{array}{c}6.118 \\
(5.999)\end{array}$ & $\begin{array}{c}17.02 \\
(12.62)\end{array}$ & $\begin{array}{c}4.966 \\
(4.768)\end{array}$ & $\begin{array}{l}1.934 \\
(5.495)\end{array}$ & $\begin{array}{l}-9.261 \\
(12.80)\end{array}$ \\
\hline Observations & 723 & 723 & 723 & 729 & 729 & 729 \\
\hline
\end{tabular}

Notes: Data from the Spanish Time Use Survey 2003 and 2009. The sample is of children aged 6 to 17 born in December or January in Spain. The first 3 columns correspond to the analysis of the sample of boys and the last 3 to the sample of girls. The outcome variables indicate the minutes a day parents spent with their children doing different activities: ones related to teaching, to reading and playing, and other childcare activities. "Young" is an indicator variable that equals one if the student was born in December and zero if she was born in January. The variable "college mother" takes value 1 if the mother of the student has a college degree and zero otherwise. All the reported models include a vector of dummies for birth cohort, and quarter and day of interview.

Standard errors are clustered at the household level. ${ }^{* * *} \mathrm{p}<0.01,{ }^{* *} \mathrm{p}<0.05,{ }^{*} \mathrm{p}<0.1$

We obtain results along the same lines using data from the General Diagnostic Assessment, which again shows that the differential compensating effect on time investment found among high-SES parents is mainly present in male students (see the results in Table B.5 in the online Appendix).

In contrast, the results for school choice are less conclusive. As Table 10 shows, the estimates for the coefficient of interest (row 3 in Panels A and B) are very imprecise and do not allow us to identify any gender pattern in terms of school choice.

To summarise, we do not find that the student outcomes or the parental responses for boys and girls from low-SES families differ according to the age at school entry. In contrast, we observe different gender patterns among children from high-SES families. On the one hand, younger boys from high-SES families do not seem to be able to overcome the age at school entry disadvantage by age 15, and probably because they face a larger disadvantage they receive more parental help with homework and other academic activities. On the other hand, younger girls do not have different achievement levels at age 15 to their older peers, and probably because they face a smaller disadvantage, they do not receive more parental help than older girls from the same SES families. Maybe girls mature faster than boys, or receive more investment than boys, and do not face a learning disadvantage at school entry, or they are able to overcome this disadvantage faster. We cannot say which of these explanations is true, but these results indicate, like those presented before, that high-SES parents invest more in their children when they are at a disadvantage at school. 
Table 10: School Choice by Student Gender

\begin{tabular}{|c|c|c|c|c|c|}
\hline & \multicolumn{5}{|c|}{ Panel A: Boys } \\
\hline & $(1)$ & $(2)$ & $(3)$ & $(4)$ & $(5)$ \\
\hline & Concertada school & Class size & Peers motivated to learn & Teacher quality index & Parental involvement index \\
\hline Youngest & 0.00366 & 0.314 & -0.0309 & 0.0228 & 0.00871 \\
\hline & $(0.0278)$ & $(0.255)$ & $(0.0307)$ & $(0.0361)$ & $(0.0441)$ \\
\hline College mother & $0.192^{* * *}$ & $1.125^{* * *}$ & $0.114^{* * *}$ & -0.00227 & -0.0315 \\
\hline & $(0.0391)$ & $(0.413)$ & $(0.0364)$ & $(0.0466)$ & $(0.0589)$ \\
\hline Youngest X College mother & $0.0967^{*}$ & -0.671 & $0.0911^{*}$ & 0.0838 & 0.114 \\
\hline & $(0.0510)$ & $(0.479)$ & $(0.0481)$ & $(0.0630)$ & $(0.0718)$ \\
\hline \multirow[t]{4}{*}{ Observations } & 1596 & 1596 & 1596 & 1596 & 1596 \\
\hline & \multicolumn{5}{|c|}{ Panel B: Girls } \\
\hline & $(1)$ & $(2)$ & $(3)$ & $(4)$ & $(5)$ \\
\hline & Concertada school & Class size & Peers motivated to learn & Teacher quality index & Parental involvement index \\
\hline \multirow[t]{2}{*}{ Youngest } & 0.00230 & 0.123 & -0.0202 & -0.0340 & -0.0239 \\
\hline & $(0.0284)$ & $(0.274)$ & $(0.0303)$ & $(0.0344)$ & $(0.0396)$ \\
\hline \multirow[t]{2}{*}{ College mother } & $0.279^{* * *}$ & $1.559^{* * *}$ & $0.166^{* * *}$ & 0.0122 & 0.0257 \\
\hline & $(0.0411)$ & $(0.288)$ & $(0.0363)$ & $(0.0458)$ & $(0.0520)$ \\
\hline \multirow[t]{2}{*}{ Youngest X College mother } & -0.0301 & -0.533 & 0.0392 & $0.109^{*}$ & 0.0719 \\
\hline & $(0.0532)$ & $(0.424)$ & $(0.0476)$ & $(0.0629)$ & $(0.0656)$ \\
\hline Observations & 1575 & 1575 & 1575 & 1575 & 1575 \\
\hline
\end{tabular}

Notes: The data come from the General Diagnostic Assessment survey 2009. The sample includes Spanish students enrolled in 4th grade who were born in December or January. Panel A analyses the sample of boys and Panel B the sample of girls. The outcome variables are different school characteristics: a concertada school indicator (Column 1), class size (Column 2), an indicator of whether the teacher reports that the students in her class are very motivated (Column 3), a Teacher Quality Index (Column 4) and a Parental Involvement Index (Column 5). "Young" is an indicator variable that equals one if the student was born in December and zero if she was born in January. The variable "college mother" takes value 1 if the mother of the student has a college degree and zero otherwise. All reported models include a vector of dummies for birth cohort, and quarter and day of interview. Standard errors are clustered at the household level. ${ }^{* * *} \mathrm{p}<0.01, * * \mathrm{p}<0.05,{ }^{*} \mathrm{p}<0.1$ 


\section{Conclusions}

To understand inequality in human capital it is necessary to understand how parental investment varies according to socioeconomic status. Our results contribute to this goal by providing evidence on how parents react to a widely-used school policy that puts younger children at a learning disadvantage. They show that parental responses vary with socioeconomic status.

Highly-educated parents compensate when their children enter school at an earlier age by spending more time helping their children with learning activities and choosing schools with better inputs for them. We do not find a similar pattern among less educated parents. This socioeconomic difference in compensating behavior can explain why the disadvantage of being young at school entry is greater for children from disadvantaged backgrounds. Interestingly, the response of highly educated parents is particularly present in the case of boys.

There is a well-established empirical relationship between parental socioeconomic status and student (and longer-term) outcomes. Genetics and differences in planned investment paths are likely to play a key role in this. Our results highlight an additional channel: differences in investment due to different responses according to parental background to policies (or potentially life shocks) that put children at a learning disadvantage. In other words, we find evidence that more educated parents are more prepared to handle disadvantage and can then protect their children from it by increasing the resources they allocate to them.

Our findings call for the design of public policies targeting those who need support the most: young children from low-SES families, presumably with a focus not only on the children, but also on parents and schools.

The results presented in this paper are also informative about the effects of teaching the same curriculum to children with different achievement levels., which is a common practice across countries. Our findings suggest that the task of dealing with a unique curriculum from the position of a learning disadvantage can be particularly daunting for children from low-SES families. Policies aiming to allow schools to teach at the right level (using some degree of tracking or supplementary activities according to achievement level) are worth exploring.

\section{References}

Albornoz, F., S. Berlinski, and A. Cabrales (2016): "Motivation, resources and the organization of the school system," Journal of the European Economic Association.

Almond, D. And B. Mazumder (2013): "Fetal Origins and Parental Responses," Annual Review of Economics, 5, 37-56. 
Bedard, K. And E. Dhuey (2006): "The Persistence of Early Childhood Maturity: International Evidence of Long-Run Age Effects," The Quarterly Journal of Economics, 121, 1437-1472.

(2012): "School-Entry Policies and Skill Accumulation Across Directly and Indirectly Affected Individuals," Journal of Human Resources, 47, 643-683.

Black, S. E., P. J. Devereux, And K. G. Salvanes (2011): "Too young to leave the nest? The effects of school starting age," The Review of Economics and Statistics, $93,455-467$.

Borra, C., L. Gonzalez, And A. Sevilla (2015): "The Impact of Scheduling Birth Early on Infant Health," Tech. rep., Barcelona Graduate School of Economics.

Buckles, K. S. And D. M. Hungerman (2013): "Season of birth and later outcomes: Old questions, new answers," Review of Economics and Statistics, 95, 711-724.

Calsamiglia, C. And A. Loviglio (2016): "Maturity and school outcomes in an inflexible system: evidence from Catalonia," .

Cook, P. J. And S. KAng (2016): "Birthdays, schooling, and crime: regressiondiscontinuity analysis of school performance, delinquency, dropout, and crime initiation," American Economic Journal: Applied Economics, 8, 33-57.

Crawford, C., L. Dearden, and C. Meghir (2007): When you are born matters: The impact of date of birth on child cognitive outcomes in England, Centre for the Economics of Education, London School of Economics and Political Science.

Das, J., S. Dercon, J. Habyarimana, P. Krishnan, K. Muralidharan, and V. Sundararaman (2013): "School inputs, household substitution, and test scores," American Economic Journal: Applied Economics, 5, 29-57.

Del Boca, D., C. Flinn, And M. Wiswall (2014): "Household choices and child development," The Review of Economic Studies, 81, 137-185.

Dhuey, E. (2016): "Age at school entry: How old is old enough?" IZA World of Labor.

Dhuey, E., D. Figlio, K. Karbownik, And J. Roth (2017): "School Starting Age and Cognitive Development," Tech. rep., National Bureau of Economic Research.

Dhuey, E. And S. Lipscomb (2008): "What makes a leader? Relative age and high school leadership," Economics of Education Review, 27, 173 - 183.

ELDER, T. E. (2010): "The importance of relative standards in ADHD diagnoses: Evidence based on exact birth dates," Journal of Health Economics, 29, 641 - 656. 
Elder, T. E. And D. H. Lubotsky (2009): "Kindergarten Entrance Age and Children's Achievement: Impacts of State Policies, Family Background, and Peers," Journal of Human Resources, 44, 641-683.

EuRYdicE (2011): "Grade Retention during Compulsory Education in Europe: Regulations and Statistics," Tech. rep., Eurydice.

Fredriksson, P. AND B. ÖCKert (2014): "Life-cycle Effects of Age at School Start," The Economic Journal, 124, 977-1004.

Fredriksson, P., B. ÖCKert, And H. Oosterbeek (2015): "Parental Responses to Public Investments in Children: Evidence from a Maximum Class Size Rule," Journal of Human Resources.

Grätz, M. And F. Bernardi (2017): "Parental Responses to Disadvantageous Life Events: The Month of Birth Penalty in England," Social Inequality Across the Generations: The Role of Compensation and Multiplication in Resource Accumulation, 68.

Grenet, J. (2011): "Academic performance, Educational Trajectories and the Persistence of Date of Birth Effects. Evidence from France," .

Landersø, R., H. S. Nielsen, and M. Simonsen (2016): "School Starting Age and the Crime-age Profile," The Economic Journal, n/a-n/a.

Mühlenweg, A. M. And P. A. Puhani (2010): "The Evolution of the School-Entry Age Effect in a School Tracking System," Journal of Human Resources, 45, 407-438.

Pop-Eleches, C. And M. Urquiola (2013): "Going to a Better School: Effects and Behavioral Responses," American Economic Review, 103, 1289-1324.

Schwandt, H. And A. Wuppermann (2016): "The youngest get the pill: ADHD misdiagnosis in Germany, its regional correlates and international comparison," Labour Economics, 43, $72-86$.

Todd, P. E. And K. I. Wolpin (2003): "On The Specification and Estimation of The Production Function for Cognitive Achievement," Economic Journal, 113, F3-F33. 


\section{Appendix}

\section{Tables: Summary Statistics}

Table A.1: Spanish Birth Certificates: Summary Statistics

\begin{tabular}{lcc}
\hline \hline & $(1)$ & $(2)$ \\
& All & Dec and Jan \\
\hline \multirow{3}{*}{ College mother } & 0.202 & 0.201 \\
& $(0.402)$ & $(0.401)$ \\
Mother lives with partner & 0.919 & 0.916 \\
& $(0.273)$ & $(0.278)$ \\
Spanish mother & 0.828 & 0.825 \\
& $(0.377)$ & $(0.380)$ \\
Mother's age & 32.00 & 32.03 \\
& $(5.170)$ & $(5.209)$ \\
Number of children & 1.615 & 1.614 \\
& $(0.783)$ & $(0.788)$ \\
Born prematurely & 0.0778 & 0.0798 \\
Cesarean sections & $(0.268)$ & $(0.271)$ \\
& 0.244 & 0.245 \\
Low birth weight & $(0.430)$ & $(0.430)$ \\
& 0.0822 & 0.0851 \\
Observations & $(0.275)$ & $(0.279)$ \\
\hline \hline
\end{tabular}

Notes: Data from Spanish birth certificates from July 2007 to June 2014 (except for July 2010-June 2011). Column 1 reports means and standard errors, in parentheses, for the full sample and Column 2 for those born in December and January. 
Table A.2: Programme for International Student Assessment: Summary Statistics

\begin{tabular}{lcc}
\hline \hline \multirow{4}{*}{ Girl } & $(1)$ & $(2)$ \\
& All & Dec and Jan \\
\hline \multirow{3}{*}{ Repeater } & 0.501 & 0.507 \\
& $(0.500)$ & $(0.500)$ \\
Times repeated & 0.276 & 0.280 \\
& $(0.447)$ & $(0.449)$ \\
Maths & 0.335 & 0.344 \\
& $(0.586)$ & $(0.597)$ \\
Reading & 501.2 & 499.3 \\
& $(83.51)$ & $(84.32)$ \\
& 492.3 & 491.2 \\
Observations & $(83.64)$ & $(84.72)$ \\
\hline \hline
\end{tabular}

Notes: Data on Spanish students aged 15 assessed in PISA 2003, 2006, 2009 and 2012. Repeater is an indicator of whether the student repeated a grade at least once, and maths and reading scores represent the performance of the student in the PISA tests. Column 1 reports means and the standard errors, in parentheses, for the full sample and Column 2 for those born in December and January. 
Table A.3: Spanish Population Census: Summary Statistics

\begin{tabular}{lcc}
\hline \hline & $(1)$ & $(2)$ \\
& All & Dec and Jan \\
\hline \multirow{2}{*}{ Age } & 42.82 & 42.60 \\
& $(7.312)$ & $(7.346)$ \\
Female & 0.501 & 0.501 \\
& $(0.500)$ & $(0.500)$ \\
College graduate & 0.145 & 0.143 \\
& $(0.352)$ & $(0.350)$ \\
Employed & 0.684 & 0.680 \\
& $(0.465)$ & $(0.466)$ \\
Married & 0.637 & 0.637 \\
Partner is college graduate & 0.121 & $(0.481)$ \\
& $(0.326)$ & 0.119 \\
& & \\
Observations & $1,373,194$ & 226,454 \\
\hline \hline
\end{tabular}

Notes: Data from the 2011 Spanish Census (IPUMS). The sample includes Spanish individuals born in December and January aged 30 to 55 at the moment of the census. The variables are indicator dummies of whether the individual is a college graduate, whether $\mathrm{s} / \mathrm{he}$ is married, and whether $\mathrm{s} /$ he was employed at the moment of the census. Column 1 reports means and the standard errors in parentheses for the full sample and Column 2 for those born in December and January. 
Table A.4: General Diagnostic Assessment: Summary Statistics

\begin{tabular}{|c|c|c|}
\hline & $\begin{array}{l}1) \\
\text { All } \\
\end{array}$ & $\begin{array}{c}(2) \\
\text { Dec and Jan }\end{array}$ \\
\hline Girl & $\begin{array}{c}0.499 \\
(0.500)\end{array}$ & $\begin{array}{c}0.495 \\
(0.500)\end{array}$ \\
\hline College mother & $\begin{array}{c}0.298 \\
(0.457)\end{array}$ & $\begin{array}{c}0.304 \\
(0.460)\end{array}$ \\
\hline Help with homework & $\begin{array}{c}0.861 \\
(0.346)\end{array}$ & $\begin{array}{c}0.856 \\
(0.351)\end{array}$ \\
\hline Parents check homework & $\begin{array}{c}0.693 \\
(0.461)\end{array}$ & $\begin{array}{c}0.687 \\
(0.464)\end{array}$ \\
\hline Parents go to school meetings & $\begin{array}{c}0.579 \\
(0.494)\end{array}$ & $\begin{array}{c}0.586 \\
(0.493)\end{array}$ \\
\hline Concertada school & $\begin{array}{c}0.396 \\
(0.489)\end{array}$ & $\begin{array}{c}0.401 \\
(0.490)\end{array}$ \\
\hline Class size & $\begin{array}{l}23.90 \\
(3.901)\end{array}$ & $\begin{array}{c}23.87 \\
(4.067)\end{array}$ \\
\hline Peers motivated to learn & $\begin{array}{c}0.704 \\
(0.456)\end{array}$ & $\begin{array}{c}0.691 \\
(0.462)\end{array}$ \\
\hline Parental interest in learning problems & $\begin{array}{c}0.284 \\
(0.451)\end{array}$ & $\begin{array}{c}0.289 \\
(0.453)\end{array}$ \\
\hline Parental interest in grades & $\begin{array}{c}0.385 \\
(0.487)\end{array}$ & $\begin{array}{c}0.384 \\
(0.487)\end{array}$ \\
\hline Parents attend meetings & $\begin{array}{c}0.481 \\
(0.500)\end{array}$ & $\begin{array}{c}0.481 \\
(0.500)\end{array}$ \\
\hline Teachers continual training & $\begin{array}{c}0.791 \\
(0.406)\end{array}$ & $\begin{array}{c}0.789 \\
(0.408)\end{array}$ \\
\hline Teachers target students with learning disadvantages & $\begin{array}{c}0.604 \\
(0.489)\end{array}$ & $\begin{array}{c}0.616 \\
(0.486)\end{array}$ \\
\hline Teachers follow students' progress daily & $\begin{array}{c}0.704 \\
(0.456)\end{array}$ & $\begin{array}{c}0.706 \\
(0.456)\end{array}$ \\
\hline Observations & 18,583 & 3,085 \\
\hline
\end{tabular}

Notes: The data comes from the General Diagnostic Assessment survey 2009. The sample includes Spanish students enrolled in 4th grade. The variable "college mother" takes value 1 if the mother of the student has a college degree and zero otherwise. "Concertada school" takes value 1 if the school is privately managed and is zero otherwise. Class size indicates the number of students in the class. The rest of the variables are indicators about parental involment in their children education (measured in a student survey) and school inputs (measured in surveys to parents and school principals). Column 1 reports means and standard deviations in parentheses for the full sample and Column 2 for those born in December and January. 
Table A.5: Spanish Time Use Surveys 2003 and 2009: Summary Statistics

\begin{tabular}{lcc}
\hline \hline & $(1)$ & $(2)$ \\
& All & Dec and Jan \\
\hline \multirow{3}{*}{ Girl } & & \\
& 0.484 & 0.500 \\
College mother & $(0.500)$ & $(0.500)$ \\
\multirow{2}{*}{ Time spent teaching } & 0.364 & 0.364 \\
& $(0.481)$ & $(0.481)$ \\
Time spent reading and playing & 7.690 & 7.546 \\
& $(25.51)$ & $(24.88)$ \\
Childcare Time & 22.71 & 22.64 \\
& $(53.28)$ & $(51.98)$ \\
& 86.21 & 85.74 \\
Observations & $(118.9)$ & $(118.6)$ \\
\hline \hline
\end{tabular}

Notes: Data from the Spanish Time Use Survey 2003 and 2009. The sample is of children aged 0 to 17 born in Spain. The variable "college mother" takes value 1 if the mother of the student has a college degree and zero otherwise. The other variables indicate the minutes a day parents spent with their children doing different activities: ones related to teaching, reading and playing, and other childcare activities. Column 1 reports means and standard deviations, in parentheses for the full sample and Column 2 for those born in December and January. 


\section{Online Appendix}

Figure B.1: School Performance at age 15: Young vs. Old According to SES

\section{Repeater}

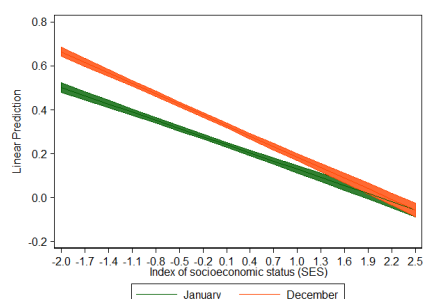

Maths score

\section{Reading score}
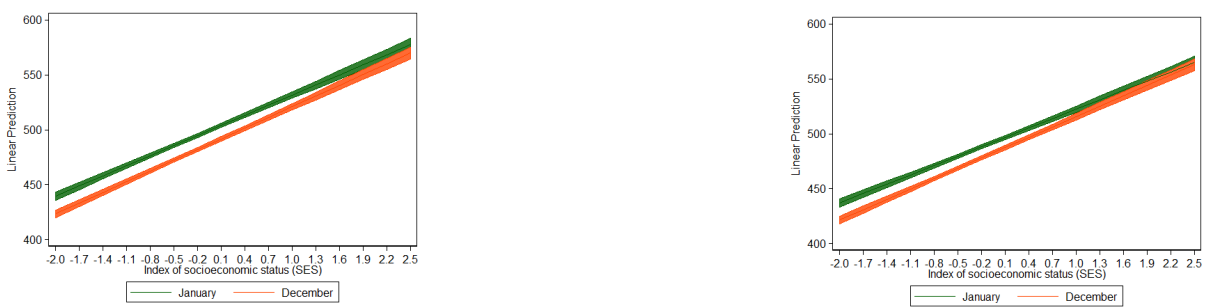

Notes: Data on Spanish students aged 15 assessed in PISA 2003, 2006, 2009 and 2012. For young (born in December) and old (born in January) students the figures plot the predicted marginal effect of socio-economic status on: the probability of having repeated at least one grade (top), and the mean test score in maths and reading at PISA (bottom). Point estimates and 95\% confidence intervals. 
Table B.1: School Choice

\begin{tabular}{lcc}
\hline \hline & $(1)$ & $(2)$ \\
& Parental survey & Student survey \\
\hline Youngest & 0.0194 & 0.00643 \\
& $(0.0220)$ & $(0.0193)$ \\
College mother & $-0.0907^{* * *}$ & -0.0189 \\
& $(0.0298)$ & $(0.0224)$ \\
Youngest X College mother & -0.0455 & $-0.0640^{* *}$ \\
& $(0.0386)$ & $(0.0315)$ \\
Girl & 0.00401 & -0.0205 \\
& $(0.0177)$ & $(0.0152)$ \\
\hline Observations & 3292 & 3292 \\
\hline \hline
\end{tabular}

Notes: The data come from the General Diagnostic Assessment survey 2009. The sample includes Spanish students enrolled in 4th grade who were born in December or January. The outcome variables is an indicator of whether the parent (Column 1) or the student (Column 2) declare (in separate surveys) if the student is enrolled in her current school because s/he lives in the school's catchment area. "Young" is an indicator variable that equals one if the student was born in December and zero if she was born in January. The variable "college mother" takes value 1 if the mother of the student has a college degree and zero otherwise. Standard errors are clustered at the school level. * $\mathrm{p}<0.10, * * \mathrm{p}<0.05, * * * \mathrm{p}<0.01$ 
Figure B.2: Birth Characteristics and Month of Birth

\section{All mothers}

College

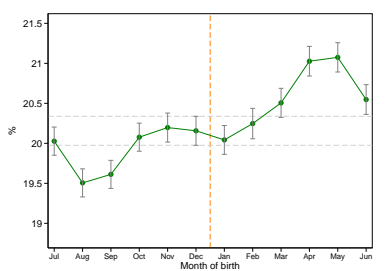

Spanish

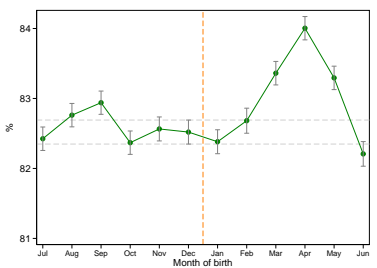

In a couple

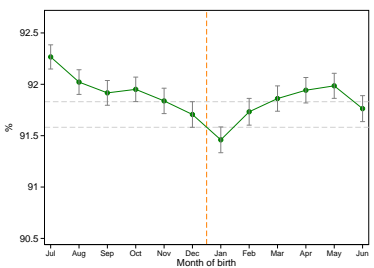

Age

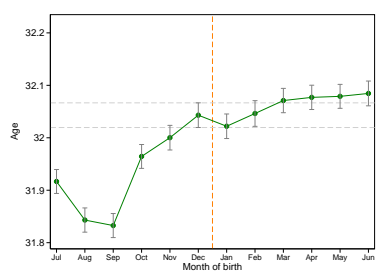

Number of children

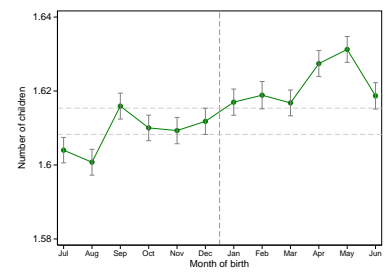

Poorly educated mothers

Spanish

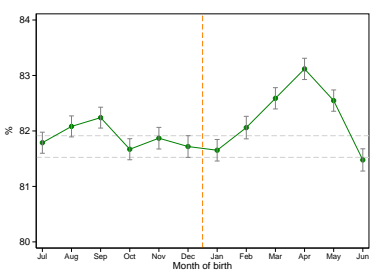

Age

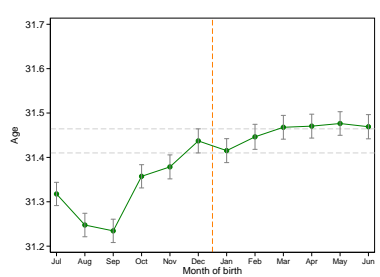

In a couple

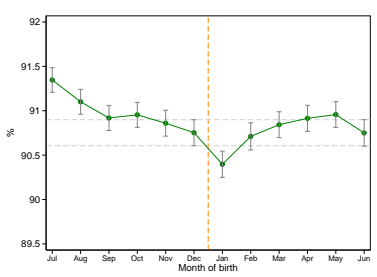

Number of children

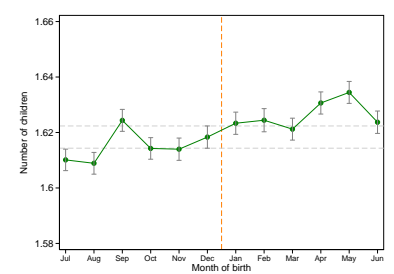

Highly educated mothers

Spanish

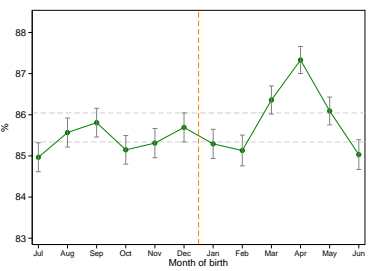

Age

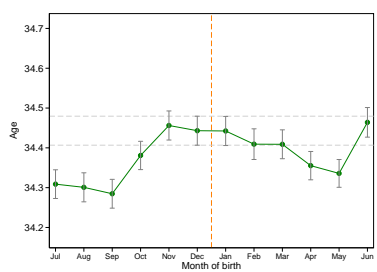

In a couple

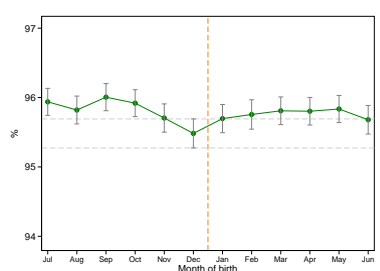

Number of children

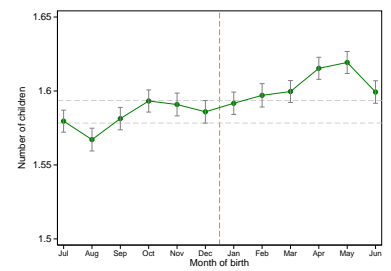

Notes: The data come from Spanish birth certificates. The sample includes the universe of Spanish newborns (first five figures), Spanish babies born from non-college graduate mothers (four figures in the middle) or from college educated mothers (last four figures) in the period 2007-2014 (except for July 2010-June 2011). The figures plot, by month of birth, the percentage of babies born from mothers with a college degree, from Spanish mothers, from mothers living in a couple, and the average age of the mothers of the newborns or the average number of children of their mothers.. Means are represented by dots and 95\% confidence intervals are in graj36 
Table B.2: School Quality Index

\begin{tabular}{|c|c|c|c|c|c|c|c|c|c|c|}
\hline & \multirow{2}{*}{$\frac{\text { School quality index }}{(1)}$} & \multirow{2}{*}{$\begin{array}{c}\text { Private school } \\
(2)\end{array}$} & \multirow{2}{*}{$\begin{array}{l}\text { Class size } \\
(3)\end{array}$} & \multirow{2}{*}{$\begin{array}{l}\text { Peers motivated to learn } \\
(4)\end{array}$} & \multicolumn{3}{|c|}{ Teacher quality index } & \multicolumn{3}{|c|}{ Family peers motivation index } \\
\hline & & & & & $\begin{array}{c}(5) \\
\text { Teachers } \\
\text { continual training }\end{array}$ & $\begin{array}{c}(6) \\
\text { Teachers target } \\
\text { students with } \\
\text { learning disadvantages }\end{array}$ & $\begin{array}{c}\text { (7) } \\
\text { Teachers follow } \\
\text { students' progress daily }\end{array}$ & $\begin{array}{c}(8) \\
\text { Parents attend } \\
\text { meetings }\end{array}$ & $\begin{array}{c}(9) \\
\text { Parental interest } \\
\text { in learning problems }\end{array}$ & $\begin{array}{l}(10) \\
\text { Parental interest } \\
\text { in grades }\end{array}$ \\
\hline Youngest & $\begin{array}{c}-0.0154 \\
(0.0180)\end{array}$ & $\begin{array}{l}0.00610 \\
(0.0437)\end{array}$ & $\begin{array}{l}-0.0495 \\
(0.0415)\end{array}$ & $\begin{array}{c}-0.0540 \\
(0.0450)\end{array}$ & $\begin{array}{c}-0.0559 \\
(0.0441)\end{array}$ & $\begin{array}{l}-0.0167 \\
(0.0434)\end{array}$ & $\begin{array}{c}0.0547 \\
(0.0441)\end{array}$ & $\begin{array}{c}-0.000693 \\
(0.0425)\end{array}$ & $\begin{array}{l}-0.0111 \\
(0.0444)\end{array}$ & $\begin{array}{c}-0.0119 \\
(0.0437)\end{array}$ \\
\hline College mother & $\begin{array}{l}0.00331 \\
(0.0238)\end{array}$ & $\begin{array}{c}0.0272 \\
(0.0608)\end{array}$ & $\begin{array}{l}0.00164 \\
(0.0728)\end{array}$ & $\begin{array}{l}0.00686 \\
(0.0628)\end{array}$ & $\begin{array}{c}0.0128 \\
(0.0560)\end{array}$ & $\begin{array}{c}-0.0245 \\
(0.0630)\end{array}$ & $\begin{array}{c}0.0225 \\
(0.0607)\end{array}$ & $\begin{array}{c}-0.0192 \\
(0.0634)\end{array}$ & $\begin{array}{r}-0.00843 \\
(0.0648)\end{array}$ & $\begin{array}{c}0.0109 \\
(0.0655)\end{array}$ \\
\hline Youngest X College mother & $\begin{array}{c}0.106 * * * \\
(0.0299)\end{array}$ & $\begin{array}{c}0.0719 \\
(0.0755)\end{array}$ & $\begin{array}{c}0.143 * \\
(0.0843)\end{array}$ & $\begin{array}{l}0.155 * * \\
(0.0775)\end{array}$ & $\begin{array}{l}0.166 * * \\
(0.0727)\end{array}$ & $\begin{array}{l}0.158 * * \\
(0.0804)\end{array}$ & $\begin{array}{l}-0.0287 \\
(0.0760)\end{array}$ & $\begin{array}{l}0.154 * * \\
(0.0747)\end{array}$ & $\begin{array}{c}0.0181 \\
(0.0779)\end{array}$ & $\begin{array}{c}0.116 \\
(0.0786)\end{array}$ \\
\hline Girl & $\begin{array}{l}0.00382 \\
(0.0133)\end{array}$ & $\begin{array}{c}0.0338 \\
(0.0357)\end{array}$ & $\begin{array}{c}-0.0354 \\
(0.0336)\end{array}$ & $\begin{array}{l}-0.0175 \\
(0.0351)\end{array}$ & $\begin{array}{l}0.00120 \\
(0.0342)\end{array}$ & $\begin{array}{l}0.00485 \\
(0.0350)\end{array}$ & $\begin{array}{c}0.0186 \\
(0.0355)\end{array}$ & $\begin{array}{l}0.00287 \\
(0.0352)\end{array}$ & $\begin{array}{c}-0.000826 \\
(0.0343)\end{array}$ & $\begin{array}{c}0.0267 \\
(0.0343)\end{array}$ \\
\hline Observations & 3171 & 3171 & 3171 & 3171 & 3171 & 3171 & 3171 & 3171 & 3171 & 3171 \\
\hline
\end{tabular}

Notes: The data come from the General Diagnostic Assessment survey 2009. The sample includes Spanish students enrolled in 4 th grade who were born in December or January. The outcome variables are an Index of School Quality (Column 1 ) and the different school character-
istics to involvement (columns 8 to 10). "Young" is an indicator variable that equals one if the student was born in December and zero if she was born in January. The variable "college mother" takes value 1 if the mother of the student has a college degree and zero otherwise. Standard 
Table B.3: Parental Time investment - Summer excluded

\begin{tabular}{lccc}
\hline \hline & $(1)$ & $(2)$ & $(3)$ \\
& Teaching & Reading and Playing & Other childcare \\
\cline { 2 - 4 } Youngest & -0.298 & -0.468 & -4.490 \\
& $(1.428)$ & $(2.870)$ & $(6.957)$ \\
College mother & 0.788 & $12.46^{* * *}$ & $36.49^{* * *}$ \\
& $(1.830)$ & $(3.877)$ & $(9.738)$ \\
Youngest X College Mother & $6.918^{* *}$ & 2.549 & -2.203 \\
Girl & $(3.163)$ & $(5.278)$ & $(12.38)$ \\
& 0.719 & -1.705 & -8.382 \\
& $(1.337)$ & $(2.517)$ & $(5.674)$ \\
\hline Observations & & & 1,688 \\
\hline \hline
\end{tabular}

Notes: Data from the Spanish Time Use Survey 2003 and 2009 (summer excluded). The sample is of children aged 0 to 17 born in December or January in Spain. The outcome variables indicate the minutes a day parents spent with their children doing different activities: ones related to teaching (Column 1), reading and playing (Column 2), and other childcare activities (Column 3). "Young" is an indicator variable that equals one if the student was born in December and zero if she was born in January. The variable "college mother" takes value 1 if the mother of the student has a college degree and zero otherwise. All the reported models include a vector of dummies for birth cohort, and quarter and day of interview. Standard errors are clustered at the household level. ${ }^{* * *} \mathrm{p}<0.01,{ }^{* *} \mathrm{p}<0.05,{ }^{*} \mathrm{p}<0.1$ 
Table B.4: Parental Time Investment by Age Groups - Summer excluded

\begin{tabular}{|c|c|c|c|c|c|c|c|c|c|}
\hline & $\begin{array}{c}(1) \\
\text { Teaching }\end{array}$ & $\begin{array}{c}(2) \\
\text { Reading and Playing }\end{array}$ & $\begin{array}{c}\text { (3) } \\
\text { Other childcare }\end{array}$ & $\begin{array}{c}(4) \\
\text { Teaching }\end{array}$ & $\begin{array}{c}(5) \\
\text { Reading and Playing }\end{array}$ & $\begin{array}{c}(6) \\
\text { Other childcare }\end{array}$ & $\begin{array}{c}(7) \\
\text { Teaching }\end{array}$ & $\begin{array}{c}\text { (8) } \\
\text { Reading and Plaving }\end{array}$ & $\begin{array}{c}(9) \\
\text { Other childcare }\end{array}$ \\
\hline & & $0-5$ & & & $6-12$ & & & $13-17$ & \\
\hline Youngest & $\begin{array}{l}-0.344 \\
(2.024)\end{array}$ & $\begin{array}{l}-2.206 \\
(7.843)\end{array}$ & $\begin{array}{l}-1.829 \\
(16.38)\end{array}$ & $\begin{array}{l}-1.185 \\
(2.908)\end{array}$ & $\begin{array}{c}2.282 \\
(3.591)\end{array}$ & $\begin{array}{c}11.88 \\
(7.803)\end{array}$ & $\begin{array}{l}-0.354 \\
(2.089)\end{array}$ & $\begin{array}{l}4.141^{* *} \\
(1.901)\end{array}$ & $\begin{array}{l}-0.710 \\
(5.366)\end{array}$ \\
\hline College mother & $\begin{array}{c}2.526 \\
(2.655)\end{array}$ & $\begin{array}{c}12.00 \\
(8.132)\end{array}$ & $\begin{array}{c}32.66^{*} \\
(17.86)\end{array}$ & $\begin{array}{c}-0.127 \\
(3.666)\end{array}$ & $\begin{array}{l}8.529^{*} \\
(4.436)\end{array}$ & $\begin{array}{l}21.25^{*} \\
(11.20)\end{array}$ & $\begin{array}{c}0.567 \\
(2.699)\end{array}$ & $\begin{array}{c}0.376 \\
(1.344)\end{array}$ & $\begin{array}{l}-3.971 \\
(5.003)\end{array}$ \\
\hline Youngest X College Mother & $\begin{array}{l}-2.660 \\
(3.704)\end{array}$ & $\begin{array}{c}4.630 \\
(11.29)\end{array}$ & $\begin{array}{l}-11.76 \\
(24.54)\end{array}$ & $\begin{array}{l}15.03^{* *} \\
(6.425)\end{array}$ & $\begin{array}{l}3.030 \\
(7.146)\end{array}$ & $\begin{array}{l}-7.867 \\
(14.49)\end{array}$ & $\begin{array}{l}9.166 \\
(5.760)\end{array}$ & $\begin{array}{l}-2.656 \\
(2845)\end{array}$ & $\begin{array}{c}9.835 \\
(7.849)\end{array}$ \\
\hline Girl & $\begin{array}{l}1.057 \\
(1.859)\end{array}$ & $\begin{array}{l}-2.101 \\
(6.079)\end{array}$ & $\begin{array}{l}-4.121 \\
(11.73)\end{array}$ & $\begin{array}{c}-1.074 \\
(2.619)\end{array}$ & $\begin{array}{l}-0.937 \\
(3.131)\end{array}$ & $\begin{array}{c}-15.30^{* *} \\
(6.529)\end{array}$ & $\begin{array}{c}2.361 \\
(2.093)\end{array}$ & $\begin{array}{l}-1.680 \\
(1.499)\end{array}$ & $\begin{array}{l}-3.170 \\
(4.103)\end{array}$ \\
\hline Observations & 569 & 569 & 569 & 639 & 639 & 639 & 480 & 480 & 480 \\
\hline
\end{tabular}

Notes: Data from the Spanish Time Use Survey 2003 and 2009 (summer excluded). The sample is of children aged 0 to 17 born in December or January in Spain. The first 3 columns include only children younger than 6, columns 4 to 6 include children aged 6 to 12 and the last 3 columns include children aged 13 to 17 . The outcome variables indicate the minutes a day parents spent with their children doing different activities: ones "college mother" takes value 1 if the mother of the student has a college degree and zero otherwise. All the reported models include a vector of dummies for birth cohort, and quarter and day of interview. Standard errors are clustered at the household level. ${ }^{* * *} \mathrm{p}<0.01,{ }^{* *} \mathrm{p}<0.05,{ }^{*} \mathrm{p}<0.1$ 
Table B.5: Parental Involvement by Student Gender

\begin{tabular}{|c|c|c|c|c|c|c|}
\hline & \multicolumn{3}{|c|}{ Boys } & \multicolumn{3}{|c|}{ Girls } \\
\hline & $\begin{array}{c}(1) \\
\text { Help with homework }\end{array}$ & $\begin{array}{c}(2) \\
\text { Parents check homework }\end{array}$ & $\begin{array}{c}(3) \\
\text { Parents go to school meetings }\end{array}$ & $\begin{array}{c}(4) \\
\text { Help with homework }\end{array}$ & $\begin{array}{c}(5) \\
\text { Parents check homework }\end{array}$ & $\begin{array}{c}(6) \\
\text { Parents go to school meetings }\end{array}$ \\
\hline Youngest & $\begin{array}{l}-0.0324 \\
(0.0227)\end{array}$ & $\begin{array}{l}-0.00399 \\
(0.0279)\end{array}$ & $\begin{array}{l}-0.0428 \\
(0.0267)\end{array}$ & $\begin{array}{l}0.0407^{*} \\
(0.0224)\end{array}$ & $\begin{array}{l}0.00981 \\
(0.0260)\end{array}$ & $\begin{array}{c}-0.00318 \\
(0.0296)\end{array}$ \\
\hline College mother & $\begin{array}{c}0.0266 \\
(0.0239)\end{array}$ & $\begin{array}{c}-0.0909^{* *} \\
(0.0376)\end{array}$ & $\begin{array}{l}-0.0460 \\
(0.0378)\end{array}$ & $\begin{array}{c}0.0419 \\
(0.0297)\end{array}$ & $\begin{array}{r}-0.127^{* * *} \\
(0.0383)\end{array}$ & $\begin{array}{r}-0.00478 \\
(0.0391)\end{array}$ \\
\hline Youngest X College mother & $\begin{array}{c}0.0934^{* * *} \\
(0.0329)\end{array}$ & $\begin{array}{c}0.104^{* *} \\
(0.0509)\end{array}$ & $\begin{array}{l}0.0950^{*} \\
(0.0537)\end{array}$ & $\begin{array}{c}0.0587 \\
(0.0367) \\
\end{array}$ & $\begin{array}{c}0.0444 \\
(0.0515)\end{array}$ & $\begin{array}{c}-0.0115 \\
(0.0522) \\
\end{array}$ \\
\hline Observations & 1743 & 1687 & 1687 & 1718 & 1663 & 1658 \\
\hline
\end{tabular}

Notes: The data comes from the General Diagnostic Assessment survey 2009. The sample includes Spanish students enrolled in 4th grade who were born in December or in January. Columns 1 to 3 analyse the sample of boys and columns 4 to 6 the sample of girls. The outcome variables are different measures of parental involvement in children's education: a variable indicating whether parents help their children with their homework (Column 1), an indicator variable of parents checking children's homework (Column 2), and a variable indicating whether parents frequently go to school meetings (Column 3). "Young" is an indicator variable that equals one if the student was birth colot, all quar a 